\section{Genesis, Provenance and Classification of Rocks within the Chert Group in Central Europe}

\author{
Michael Brandl
}

hauptsächlich auf das Fehlen eines allgemein anerkannten Klassifikationssystems zurückzuführen, was sich auf internationaler Arbeitsbasis zusätzlich verschärfend auswirkt. Der Hauptgrund für diesen Umstand liegt darin, dass $\mathrm{SiO}_{2}{ }^{-}$ Modifikationen nie den Hauptfokus der Erdwissenschaften bildeten, was zuweilen unpräzise Definitionen solcher Rohstoffe zur Folge hatte. Die bedeutendsten $\mathrm{SiO}_{2}$-Rohmaterialien, die prähistorisch zur Herstellung geschlagener Steingeräte genützt wurden, sind Silizite und gehören somit der Chert-Gruppe an, wie z. B. Chert, Flint, Radiolarit etc. Dieser Beitrag ist eine überarbeitete und erweiterte Version eines im Jahr 2010 publizierten Klassifikationssystems für Gesteine der Chert-Gruppe. Das vorgeschlagene Bestimmungssystem basiert auf archäologischen, mineralogischen und geologischen Anforderungen und soll Archäologen, die mit lithischen Materialien arbeiten, als handhabbares „research tool“ dienen.

\section{Schlüsselwörter}

Chert-Gruppe, Genese, Terminologie, Archäologie, Petrographie, Mikropaläontologie, Klassifikationssystem.

\section{Introduction}

Lithic provenance studies in an archaeological context are mainly concerned with the identification of the presence and consequently the use of local versus non-local raw materials (“exotic materials”). Research questions dependent on such provenance studies frequently examine interactions between communities, transfer of knowledge and goods, early patterns of exchange and the exploitation and use of certain raw materials for the production of "expedient" or "formal" tools. Furthermore, the selection of raw materials for the manufacture of stone tools often depends 
on raw material properties and can also be influenced by certain preferences due to various reasons (e.g. sociocultural and political). These considerations are fundamental attributes of prehistoric resource management. Diverging theoretical models that consider whether or not the raw material composition in lithic assemblages represents meaningful human behaviour add to the complexity when studying mechanisms associated with prehistoric economies. Consequently, the initial step in studies based on lithic resource management is the accurate determination of all raw materials contained in archaeological assemblages, such as chert, flint, chalcedony, jasper, and others.

Nevertheless, lithic raw material determination from archaeological contexts is one of the most challenging archaeometric undertakings. This is especially true for $\mathrm{SiO}_{2}$ raw materials used for the production of chipped stone tools. These are predominantly rocks assigned to the Chert Group, generally referred to as "silicites". ${ }^{1}$ Other than for archaeologists, who are frequently forced to deal with such raw materials, silicites usually are of minor interest for geologists and mineralogists due to their oftentimes monotonous composition, resulting in statements such as: "It is all quartz anyway!” Thus, no international compulsive standards for silicite nomenclature and classification have been developed in geosciences, leaving archaeologists in a predicament. Therefore, it is understandable that researchers started to create their own determination systems, which lead to even greater confusion and exacerbating problems concerning the comparability of data sets. The need for a coherent classification system accepted by geoscientists and manageable for archaeologists became urgent with the intensification of raw material sciences in archaeological research.

The 2010 IMA-meeting in Budapest (20 th General Meeting of the International Mineralogical Association "Bonds and Bridges: Mineral Sciences and their Applications") marked a changing point for terminological issues, resulting in path-leading publications in the Archeometriai Múhely-Series of the Hungarian National Museum. ${ }^{2}$ Some years have now passed and ongoing research in the course of international projects has refined some of the initial propositions formulated by the author. ${ }^{3}$ In addition to these new implications, enhanced background information regarding the formation of chert and flint, geochemistry and alteration of silicite surfaces is provided here. The classification system proposed in the current paper is a refined version of the 2010 paper, ${ }^{4}$ which was chiefly designed for

1 Přichystal 2010, 178.

2 E.g. Biró 2010. - Götze 2010. - Přichystal 2010.

3 BRANDl 2010.

4 Brandl 2010. the determination of chert-varieties formed in genesis environments related to the Tethys Ocean. The present paper represents the scientific foundation of the " 2013 Classification System for Single Artefact Recording"5 and is intended to function as a research tool and communication catalyst between geoscientists and archaeologists.

\section{Setting the Frame: Definition of the Chert Group}

Due to their natural abundance $\mathrm{SiO}_{2}$ rocks are of major cultural importance since the beginning of stone tool manufacturing. With quartz as their dominating mineral component such rock varieties oftentimes only vary in their technical properties (e.g. texture, granularity, binding agents, etc.). Partly overlapping terminology and the additional use of an abundance of regional and common names has significantly hampered the establishment of a clear terminology and classification of such rock varieties.

Concerning the occurrence and variety of $\mathrm{SiO}_{2}$ rocks Götze states: "Silica $\left(\mathrm{SiO}_{2}\right)$ makes up 12.6 weight\% of the Earth's crust as crystalline and amorphous silica in at least 15 modifications [...], i.e. mineral phases with the formula $\mathrm{SiO}_{2}$ but a different crystal structure."

Götze suggests a fundamental petrological classification of $\mathrm{SiO}_{2}$ rocks according to their magmatic, metamorphic or sedimentary origin. ${ }^{7}$ The majority of siliceous rocks occur at the Earth`s surface, thus belonging to the group of sedimentary rocks. The group of sedimentary $\mathrm{SiO}_{2}$ rocks formed by chemical, biochemical and diagenetic $\mathrm{SiO}_{2}$ precipitation can be best subsumed under the term "silicites" as proposed by several authors. ${ }^{8}$

Prichystal defines five basic groups for prehistorically used raw materials: (1) Siliceous sediments (silicites); (2) $\mathrm{SiO}_{2}$ minerals; (3) Natural glasses; (4) Clastic silica sediments; (5) Other rocks. ${ }^{9}$

The present paper is focused on the first of these defined groups, the siliceous sediments or silicites. Genetically, silicites are non-detrital siliceous members within the group of chemical sedimentary rocks, such as limestone. Members of the Chert Group, which form the central part of this contribution, constitute the most substantial component within the sedimentary $\mathrm{SiO}_{2}$ rocks (or silicites).

According to Frondel, "chert, perhaps originally chirt, is believed to be a local English term that was taken into geological use. It may be of onomatopoeic origin. The name chert may be of more recent origin than flint, and

\footnotetext{
5 Brandl et al. in press.

6 GÖTZE 2010, 164.

7 GÖTZE 2010, 165.

8 E.g. Götze 2010. - P̌̌ichystal 2010. - P̌̌ichystal 2013.

9 P̌̌ichystal 2010, 178.
} 
unlike flint, is not found in literary usage. It was well established in meaning in 1679." ${ }^{10}$

Petrographically, chert is a crypto- to microcrystalline rock mass, with $\mathrm{SiO}_{2}$ as the principal component. In primary deposition, it occurs in the form of nodules, concretionary masses or layers (tabular chert). When broken, chert displays a conchoidal fracture and sharp edges. The hardness of chert according to Mohs is 7 (quartz).

Similarly, Pisciotto defines chert as "a hard, conchoidally fracturing, cryptocrystalline, varicolored sedimentary rock with semivitreous, vitreous, or waxy luster, consisting dominantly of silica." ${ }^{\prime 1}$

Presently, the term "chert" is replacing most of the synonyms used by archaeologists for the identification of a wide range of $\mathrm{SiO}_{2}$ modifications. However, in French and German most $\mathrm{SiO}_{2}$ varieties are still referred to as "Silex".

Before approaching further terminological issues and attempting a classification system of silicites, a fundamental backdrop concerning the raw materials under discussion needs to be provided. This includes the genesis, microstructure, geochemistry, alteration and analytical techniques used for provenance studies of rocks within the Chert Group.

\section{Genesis of Silicites/Cherts}

The source material for chert formation is $\mathrm{SiO}_{2}$. Thus, the principal research questions regarding the genesis of silicites concern the sources of chert-forming silica. There exist different genesis environments for microcrystalline $\mathrm{SiO}_{2}$ varieties referred to as "chert". Accordingly, these differences promote variation in the formation conditions, leading to an initial division into marine and lacustrine silicites.

\subsection{Genesis environments}

\subsubsection{Marine cherts}

Through time and space, there exist multiple and dynamic marine genesis environments in which chert was formed. Here, some examples for important geological settings of prehistorically utilised chert occurrences are provided following the geological timeline.

\section{Precambrian and Palaeozoic}

During the Precambrian ${ }^{12}$ and Palaeozoic periods occasional massive chert formation occurred. In Europe, Pre-

10 Frondel 1962, 223.

11 Pisciotto 1980.

12 E.g. Laschet 1984. - Sugitani et al. 2002. - Knauth, Lowe 2003. - Perry, Lefticariu 2003. - Westall et al. 2006. cambrian "iron-cherts" occur on the East European Platform, e.g. on the Baltic and Ukrainian shields. ${ }^{13}$ However, those "chert" deposits were never used for the production of chipped stone tools.

Palaeozoic cherts exist for example in the Barrandian, in the Moravo-Silesian Devonian and Lowermost Carboniferous in Poland. Practically throughout the entire Variscan Europe dark chert strata are present close to the Devonian/Lower Carboniferous border. ${ }^{14}$

\section{Triassic, Jurassic and Cretaceous}

Triassic cherts occur e.g. in northern Bavaria and Thuringia, namely Muschelkalkhornstein and Keuperhornstein. ${ }^{15}$ Similarly, deposits of Muschelkalk containing Triassic concretional cherts exist in Upper Silesia and the Cracow area. ${ }^{16}$

The Jurassic System in central Europe is divided between two dominating geotectonic domains: The (Mediterranean) Tethyan System and the (Boreal) Central European Basin System (CEBS) with attached southern EpiVariscan basins. They differ significantly in the composition of their distinctive faunal communities; however, particular faunal provinces in the boundary areas between the two domains cannot unequivocally be assigned to either of the two systems. ${ }^{17}$

\section{The Tethyan domain}

The Tethys Ocean - succeeding the Palaeo-Tethys existed mainly during the Mesozoic and the older Cenozoic period at the eastern shores of the Pangaean supercontinent. At its maximum extension, it stretched along the northeastern (= the emerging Asia) and southeastern (= eastern Gondwana) coastlines of Pangaea. This roughly correlates with the area between present-day middle Europe to the east of New Guinea. Along the Pangaean continent, the Tethys Ocean had vast shallow marginal seas, especially in the European regions. In the course of the breaking up of Pangaea into the land masses of Laurasia and Gondwana during the Jurassic period, the Tethys expanded towards Europe, converting shallow water zones and previously continental areas into deep-sea basins. During the Cretaceous era, the Tethys was closed off between the remaining parts of Gondwana. ${ }^{18}$

Both parts of Pangaea, now Africa and Europe, were situated markedly further to the south than their present

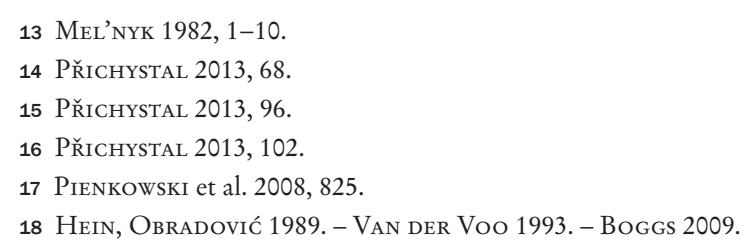


position. Thus, tropical and subtropical climatic conditions were prevalent in the Tethys area, producing coral reefs and abundant marine fauna. ${ }^{19}$ This is the environment in which occasionally extensive chert formation linked to marine sediments occurred, mainly during Jurassic and Cretaceous times. ${ }^{20}$ Chert deposits of the Eastern Alpine realm are situated in the Tethyan System.

\section{The Central European Basin System}

The Central European Basin System (CEBS) is characterised by predominantly shallow epicontinental sea basins and extends from the southern North Sea to Poland, including Denmark, the Netherlands and northern Germany. It is located between the Baltic-east European craton in the north and northeast, the Arctic-North Atlantic rift systems in the northwest and west, and the Tethyan and central Atlantic rifts in the south and comprises a series of subbasins which developed after the Variscan orogeny. The most important of these subbasins are the NorwegianDanish Basin, the North German Basin and the Polish Basin. ${ }^{21}$

Accordingly, prehistorically important Jurassic silicite deposits of the Bohemian Massif and Poland, e.g. at the Cracow-Czestochowa Upland ("Cracow flint”), the catchment area north of Góry Swietokrzyskie (Holy Cross Mountains, "Chocolate flint"), in northern Bohemia (small occurrences at the Lusatian overthrust) and southern Moravia (e.g. Krumlovský les chert, Stránská skála chert), are connected with the CEBS. ${ }^{22}$ Additionally, chert deposits in southern Germany, e.g. the Lower Bavarian Kieselnieren-Kalke in the area between Passau and Regensburg producing the prehistorically important Ortenburg cherts and the source areas at the Franconian Alb are located in southern marginal basins of the CEBS. ${ }^{23}$

\section{Late Cretaceous epicontinental basins ${ }^{24}$}

From the Middle Cretaceous period onwards, a band of interconnected epicontinental basin systems comprising the north, Danish-Polish, central European, east European, north Caspian and Turan seas extended north of and subparallel to the Tethys. ${ }^{25}$

Upper to Late Cretaceous chalk formations containing silicites occur in epicontinental basins southwest of the

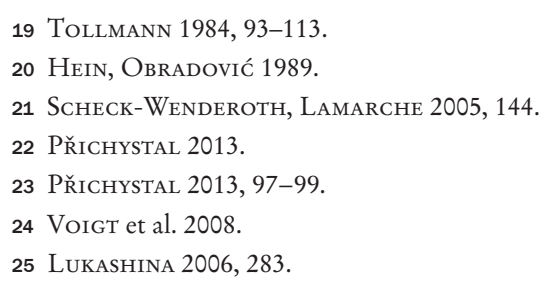

CEBS, e.g. in the Paris Basin and Mons Basin. ${ }^{26}$ In the Ukraine, such Upper Cretaceous chalk deposits are linked to basins at the southwest margin of the East European Platform. ${ }^{27}$ Cretaceous spongolites (spiculites) were formed e.g. in the Bohemian Cretaceous Basin and the Intrasudetic Basin, which were also part of Late Cretaceous epicontinental basins. ${ }^{28}$

\section{Eocene and Miocene}

Younger chert formations, predominantly of Neogene age, are known from the Eocene ${ }^{29}$ and the Miocene. ${ }^{30}$ Some of these Neogene (formerly "Tertiary") chert deposits (e.g. Collorgues in southern France and Rein in Styria, Austria) are of lacustrine origin (see below).

\subsubsection{Lacustrine cherts}

Lacustrine cherts are predominantly formed in brackish or freshwater basin environments. Sources of silica for such micro- and cryptocrystalline $\mathrm{SiO}_{2}$ modifications can vary significantly, and so do the processes of their genesis. Lacustrine chert can form as a post-depositional silification product of volcanic ashes or tuffs, evaporates or freshwater chalk in lakes or freshwater basins ${ }^{31}$ or precipitate as a result of influx of low $\mathrm{pH}$-water intermixed with silicasaturated solutions, e.g. in coastal depressions. ${ }^{32}$

\subsection{Genesis processes}

\subsubsection{Marine environments}

Most researchers assign the origin of silica in marine cherts mainly to biogene production (e.g. skeletal opal) and volcano-genetic processes, with the former prevailing. Although volcanic glasses are converted into clay minerals and zeoliths such as smectite and phillipsite during diagenesis, the formation of chert is not necessarily a consequence. In the course of the Deep See Drilling Project, many open questions concerning diagenesis ranging from the original sediments via meta-stable products of conversion to aged chert could be answered. ${ }^{33}$

For the diagenesis of marine sediments, four controlling factors can be determined: Temperature (T), burial

26 Scheck-Wenderoth et al. 2008, 1025

27 Dubicka, Peryt 2012, 210.

28 P̌̌ichystal 2013, 64-65.

29 Houser 1985. - Muttoni, Kent 2007.

30 Remicourt et al. 2009. - Brandl et al. 2011. - Weiss-Krejci, BRANDL 2011, 152.

31 Houser 1985. - Brandl et al. 2011, 57.

32 UMEDA 2003.

33 Bechter et al. 2010, 25. 
depth (z), age (a) and the host rock facies. ${ }^{34}$ Following the general scheme noncrystalline opal-A - microcrystalline opal-CT + opal-C - quartz, ${ }^{35}$ the diagenesis of biogenic sediments starts with the dissolution of organic remains caused by pressure. Under the influence of time and temperature, recrystallisation processes form amorphous opal$\mathrm{A}, \mathrm{a} \mathrm{SiO}_{2}$ modification rich in water ("skeletal opal"). In the course of dissolution processes, opal-A is transformed into crystalline opal-CT, producing small globules of ca. $5 \mu \mathrm{m}$ in size, so-called lepispheres. ${ }^{36}$ The transformation of opal-A into opal-CT in aged cherts depends on time, burial depth and temperature. During the aging of microcrystalline $\mathrm{SiO}_{2}$ modifications, the coarseness of the microstructure increases and eventually recrystallises into macroscopic quartz, which indicates the initial stages of rock metamorphosis. ${ }^{37}$

Further considerable factors for the genesis of chert and flint are the chemistry of the pore fluid, the $\mathrm{pH}$-value of the environment, the presence of clay minerals and the amount of organic material. Von Rad emphasises the importance of genesis environments for rock forming processes, stating that a transformation of opal-CT into $\alpha$-quartz takes place much faster in a calcareous milieu than in a clayish environment. ${ }^{38}$ The recrystallisation of fossil remains such as radiolarian tests (which is directly connected to the preservation of the tests in the rock matrix) is significantly limited in sediments displaying high clay (smectite) content and in carbonates. ${ }^{39}$ In the course of diagenesis, porosity decreases accompanied by compaction of the rock material and simultaneous dissolution. ${ }^{40}$

However, microfossils are not always the primary sources of silica in cherts as demonstrated by Laschet. ${ }^{41}$ This is especially true for the sometimes massive Precambrian chert deposits. Laschet distinguishes between primary and secondary chert formations, separating primary non-detrital siliceous deposits and secondary silicified organic or inorganic material. ${ }^{42}$ Two main types of silicification can be observed: (1) impregnation of a sediment or rock by silica-cement, and (2) replacement of sediment or rock by silica (forming chert nodules or banks in carbonates).

\footnotetext{
34 Murata, Larson 1975.

35 Graetsch, Grünberg 2012, 20.

36 Calvert 1974.

37 Graetsch, Grünberg 2012, 20.

38 VON RAD 1974, 1025-1036.

39 OzsváRT 2008

40 Murray 1994. - Bechter et al. 2010, 25.

41 Laschet 1984, 271-272.

42 Laschet 1984, 260.
}

For both secondary and primary cherts, Laschet proposes a different genesis model emphasising the relationship between opal- and quartz-silica phases. ${ }^{43} \mathrm{He}$ suggests an origin of (quartz-) cherts from opaline precursors, interpreting the diagenetic opal - quartz transformation as a solid - solid conversion. Silica units are reorganised in the course of recrystallisation processes, which require no intermediate solution step.

Following this model, the main factors controlling solution and precipitation of silica are $\mathrm{pH}$, temperature, the presence of $\mathrm{CO}_{2}$ and water turbulence. The predominant silica source for primary and secondary cherts is not attributed to biogenic silica, as chert formation can occur in environments lacking evidence for bioproductivity. Volcanic and other subordinate silica sources are also not considered as main suppliers of dissolved silica for extensive chert formation, since most chert deposits cannot be linked to volcanic activities, particularly secondary cherts in carbonates. According to Laschet, the main contributing silica source initiating chert formation is dissolved silica deriving from continental chemical weathering. The rate of silica input into chert forming environments is regulated by extensive global palaeoclimatic zones with ferralitic weathering. ${ }^{44}$

\subsubsection{Lacustrine environments}

Generally, silica precipitation and diagenesis can evolve very similar to the formation of marine chert; however, some processes in lacustrine chertification are still not understood to a full extent due to the diversity of possible geological settings hosting such chert deposits.

\section{Microstructure of Silicites}

Micheelsen analysed the composition and structure of Danish flint in detail. ${ }^{45}$ He determined anhedral flint grains ranging from 2 to $30 \mu \mathrm{m}$ in size, with a mean diameter of $7.5 \mu \mathrm{m}$ as the chief components of the flint. They exhibit a random orientation in the rock matrix. Every flint grain consists of a pile of quartz-plates. Every single plate can reach up to $3 \mu \mathrm{m}$ in diameter and $59 \mathrm{~nm}$ thickness and occasionally display a hexagonal shape. The plates - twinned according to the Brazil law - are comprised of subgrains measuring $30-90 \mathrm{~nm}$ in diameter. These subgrains are divided by twin faults, producing a twinning effect perpendicular to the planes of the plates and corresponding to the Dauphiné law. This creates a pseudo-hexagonal symmetry of the plates. Accordingly, the subgrains are constituted of twinned right- and left-handed $\alpha$-quartz. Imbedded

\footnotetext{
43 Laschet 1984, 257.

44 LASChet 1984, 257.

45 Micheelsen 1966.
} 
between the parallel planes of the plates is a monolayer of $\mathrm{H}_{2} \mathrm{O} .{ }^{46}$

Additional to those findings, Rottländer observed that the flint grains described by Micheelsen (1966) build up into a structure of a higher order, so-called flakes or scales. ${ }^{47}$ The planes of these scales are approximately parallel aligned with a size of up to $50 \mu \mathrm{m}$, however their general distribution is random.

Hence, the structural elements of flint in the following are starting from the smallest: (1) Subgrains $(30-90 \mathrm{~nm}) ;(2)$ Plates $(3 \mu \mathrm{m})$; (3) Grains $(2-30 \mu \mathrm{m})$; (4) Scales $(-50 \mu \mathrm{m})$.

Concerning the genesis of the grains, the main constituents of flint, Micheelsen notes: "It seems plausible that the flint grains have been formed by epitaxial replacement of the fine-grained subsidiary cryptocrystalline silica found in many Danish flint nodules". ${ }^{48}$

While Micheelsen confined his analysis to flint, Rottländer investigated alpine chert and chalcedony as well. He found identical structural elements down to the grains, the smaller elements (e.g. plates) deviated in different $\mathrm{SiO}_{2}$ modifications. Chert displays a coarser microstructure than flint whereas chalcedony is finer-grained. ${ }^{49}$

According to Rottländer, patination of chert and flint starts at the boundaries of the scales and loosens the interscale connections, resulting in the intensification of light scattering. ${ }^{50}$ This phenomenon is optically perceived as the "white patina”-effect (see below, "Alteration of silicites").

\section{Geochemistry of Silicites}

Modifications of quartz are very pure substances and contain up to $100 \mathrm{wt} \% \mathrm{SiO}_{2}$. The total concentration of trace elements typically ranges between $200-500$ ppm in chert and flint materials. As reported by Rottländer and Weymouth, inclusions such as foreign cations (ions with a positive charge) adhere to the exterior planes of the chert/ flint grains and occupy the space between the parallel aligned plates described above. ${ }^{51}$

The trace element content in silicites can be explained by the following geochemical processes:

(1) Substitution of Si in the crystal lattice by other cations: ${ }^{52}$ The substitution of $\mathrm{Si}^{4+}$ (silica) in the crystal lattice of $\mathrm{SiO}_{2}$ modifications by other cations is limited to ions with a similar ion radius and charge, such as $\mathrm{Al}^{3+}$ (aluminium), $\mathrm{Ti}^{4+}$ (titanium) $\mathrm{Ge}^{4+}$ (germanium), $\mathrm{Fe}^{3+}$ (iron) and $\mathrm{P}^{5+}$ (phos-

46 Micheelsen 1966, 360.

47 RotTLÄNDER 1975, 108.

48 Micheelsen 1966, 286.

49 RotTländer 1983, 556-557.

50 ROTTLÄNDER 1975, 108.

51 RotTläNDER, WeYMouth 1980/1981, 35.

52 Faure 1998, 99-111. phorus) (HFS-elements ${ }^{53}$ ). A charge difference of 1 is also possible, but requires additional cations or crystal defects to achieve neutrality.

(2) Deposition of chemical elements in pore spaces: ${ }^{54}$ In the case of $\mathrm{Al}^{3+}$ (aluminium) and $\mathrm{Fe}^{3+}$ (iron), additional cations such as $\mathrm{Li}^{+}$(lithium), $\mathrm{Na}^{+}$(sodium), $\mathrm{H}^{+}$(hydrogen) and $\mathrm{K}^{+}$(potassium) (LIL- elements ${ }^{55}$ ) may occupy interstitial positions in the crystal lattice. Trace elements can be deposited in pore spaces cogenetically during the sedimentation processes or secondarily in the course of diagenesis. Surface alteration processes like weathering can change the chemical composition by either removal of elements or a secondary deposition (see Heading 6).

(3) Inclusion of foreign minerals in chert/flint: Synsedimentary inclusion of foreign minerals commonly involves feldspar, carbonates and heavy-minerals (minerals with a density over $2,9 \mathrm{~g} / \mathrm{cm}^{3}$, e.g. rutile, hematite, limonite, etc.). The presence of e.g. Ca (calcium), Al (aluminium), Fe (iron), Mn (manganese), $\mathrm{Ni}$ (nickel) and $\mathrm{Cr}$ (chromium) can be assigned to such foreign inclusion minerals.

\subsection{Correlations with calcium (Ca)}

In order to evaluate the origin of trace elements in chert and flint samples in the course of geochemical investigations (e.g. LA-ICP-MS ${ }^{56}$ ), trace elements $\mathrm{Al}$ (aluminium) and $\mathrm{Mg}$ (magnesium) need to be correlated with $\mathrm{Ca}$. The element $\mathrm{Ca}$ usually occurs in chert and flint as inclusion minerals such as calcite, dolomite, or plagioclase and clay minerals. Thus, Ca correlation is useful in order to render systematic trends related to those inclusion minerals visible.

\section{Alteration of Silicites}

When exposed to weathering effects and aggressive environments, the rock surfaces of silicites are chemically altered. These effects are referred to as weathering or patination. There are various types of silicite surface patination, such as gloss patination, white patina, stain patina, or desert varnish. ${ }^{57}$ Luedtke distinguishes two forms of closely related weathering effects, chemical and mechanical. ${ }^{8}$ The predominant form of mechanical weathering is frost fracturing, chemical weathering is caused by precipitation of soluble materials from the rock surface. ${ }^{59}$

53 HFS: High field strength elements.

54 Milliken 2003, 214-218.

55 LIL: Low field strength large ion lithophile elements.

56 Laser Ablation Inductively Coupled Mass Spectrometry.

57 Howard 2002, 283-284.

58 LuedtKe 1992, 98.

59 Rottländer 1975, 109-110. 
Chemical weathering of microcrystalline $\mathrm{SiO}_{2}$ varieties in soils involves two main visible effects: white and glossy patination. Glossy patination is caused by silica deposition covering the entire rock surface with a translucent varnish. The silica is dissolved from slightly protruding areas of the rock surface and redeposited in lower parts, uniformly coating the silicite. ${ }^{60}$

According to Affolter, three main colour types of patina can be distinguished, white, brown and black. ${ }^{61}$ For white patination, Rottländer states:

"Alkaline solutions with a $\mathrm{pH}$-value above 10.0 result in white patination. These vigorously acting solvents attack the surface of chert starting at boundaries of grains at the size of only a few mymeter in magnitude. From those microfissures, a solvent penetrates into the material producing etched holes during the process of the patination. Intensity and rate of the patination is directly linked to the microstructure of the raw material." ${ }_{62}$

In other words, alkaline environments trigger the solution of silica from silicite surfaces. ${ }^{63}$ Black patination is indicative of a deposition in moist environments (e.g. lakes or bogs), brown patination derives from $\mathrm{Fe}$-intrusion in the rock surface. ${ }^{64}$

A commonly recognised form of silicite patination concerns a phenomenon paraphrased as "chert pest". ${ }^{65}$ Silicites affected by chert pest typically display a solid and oftentimes smooth surface structure, however, they are tangibly too light considering the specific weight of $\mathrm{SiO}_{2}$ modifications ( 2.6). Edge damage of such specimens reveals a transformation (weathering) of the rock structure into a very soft, chalk-like substance. XRD analyses established that the weathering by-product still consists of quartz. Chert pest has been observed in previous investigations concerning the patination of silicites, indicating a correlation between this phenomenon and depositional circumstances. ${ }^{66}$ In such cases a combination of both glossy and white patination needs to be considered.

Possible connections of those weathering phenomena are still unclear; however it is very likely that they occur interrelated. It has been observed that chert and flint artifacts with a distinct glossy surface additionally display a more porous internal structure than specimens unaffected by patination. Chemical reactions related to the patination

\footnotetext{
60 Rottländer 1975. - LuedtKe 1992.

61 Altdorfer, Affolter 2011, 39.

62 RotTläNder 1975, 107.

63 LuedtKe 1992, 99-100.

64 Altdorfer, Affolter 2011, 39.

65 Brandl et al. 2011, 59.

66 Schmalz 1960. - RotTLÄNder 1975. - RotTLL̈̈NDER 1983
}

of silicites are generally triggered by moisture. ${ }^{67}$ Chemical alteration of the inner rock structure is intensified by solutions intruding into the rock matrix through micro-cracks on the rock surfaces (e.g. from burning). There also seems to exist a direct link between patination and environmental influences, e.g. lichens breaking up rock surfaces. ${ }^{68}$

\section{Silicite Provenance Studies: Analytical Techniques}

In transdisciplinary studies, both archaeologists and mineralogists are concerned with the determination and subsequently - with provenance studies of rocks used for stone tool production in prehistoric and historic times. The first and essential step for any scientific investigation involving raw materials is the accurate determination of these materials.

\subsection{Visual (macroscopic) determination}

Purely visual rock identification is a risky undertaking; however, certain attributes afford preliminary assessments. These involve colour information, knapping properties (quality), texture (granularity and homogeneity of the material) and hardness.

\subsubsection{Scratch test}

The macroscopic assignment of a rock to $\mathrm{SiO}_{2}$ modifications can be achieved by applying a simple test. A steel nail has a hardness of 6 on the Mohs scale, whereas quartz displays a hardness of 7 . Thus, when scratching a $\mathrm{SiO}_{2}$ rock surface, material from the nail will remain on the harder rock visible as silver-grey (metal) streak. If the streak appears whitish in combination with a powdery abrasion the rock consists of softer material and a silicite can be excluded. Rocks other than quartz with hardness 7 or above are very rare in archaeological contexts making the scratch test a suitable criterion for an initial determination.

\subsection{Microscopic analysis}

The investigation of rocks under the reflected light stereomicroscope helps to identify most of the inclusions present in silicites. The goal of such investigations is the determination of characteristic microfossil inclusions and - in the best case - fauna communities indicating the age and origin of a chert or flint. Micropalaeontological investigations are typically conducted on polished specimens. However, archaeological material requires non-destructive analysis methods. Thus, comparative micropictures for the

67 Burronia et al. 2002, 1281-1282.

68 AcKerman 1964, 386-387. - RotTlLÄNder 1983, 560-561. - BuRRONIA et al. 2002, 1281. 
present study are almost exclusively produced from unpolished rock surfaces of representative samples.

\subsubsection{Water immersion}

In order to minimise contrast-reducing reflexions on rock surfaces, a method referred to as "water immersion" is applied. A drop of water on the surface compensates the effect of changes of the refractive index at air-water or airmaterial borders. The visibility of inclusions and structures within the investigated material is significantly increased using water immersion, because it functions as a magnification and clarification agent.

\subsubsection{Carbonate test}

Applying diluted hydrochlotc acid (Hcl; typically $3-5 \%$ ) on a rock surface affords the determination of carbonates within the rock. The chemical reaction of carbonates with $\mathrm{Hcl}$ (or other kinds of acids, e.g. concentrated vinegar) produces $\mathrm{CO}_{2}$ on the tested surface, visible as foaming effect. This effect can also be observed with the naked eye, however, when testing artefacts only small amounts should be applied to avoid permanent changes of the rock structure. Thus, the test is best performed under a microscope.

The carbonate test enables researchers to differentiate between (1) silicites (typically contain carbonates in the cortex region) and inorganic $\mathrm{SiO}_{2}$ modifications (with no carbonates present) and (2) between silicites (siliceous matrix, carbonates are rarely present) and siliceous limestone (silicified, but still containing significant amounts of carbonates, e.g. calcite).

\subsection{Petrographic-mineralogical analysis}

In some cases, it is necessary to conduct mineralogical investigations in conjunction with the above mentioned techniques for secure rock identification. The following methods proved to be useful for raw material determination; indeed they only represent a selection of all available methods. However, these are the techniques frequently used in the course of raw material studies at the Austrian Academy of Sciences.

\subsubsection{X-Ray Diffraction (XRD)}

The mineral content can be determined applying XRD, a technique for analysing a wide range of crystalline materials. This method allows for the detection of crystalline mineral components in small amounts. The detection limit, typically ranging between $2-3$ vol.\%, highly depends on the analysed minerals.

\subsubsection{Scanning Electron Microscopy (SEM)}

Secondary electron images displaying the surface of the samples can be obtained by a scanning electron microscope. The electrons interact with the atoms of the sample producing signals that contain information about the surface topography, material composition and other properties of the sample. Non-destructive SEM imaging is possible applying an environmental SEM unit (ESEM), which allows surface scanning without gold or carbon coating.

\subsection{Geochemical analysis}

Geochemistry has widely been employed for chert source provenance studies in various projects. ${ }^{69}$ For geochemical analysis, LA-ICP-MS has been successfully applied during the last years. This method allows for a spatially resolved detection of trace elements with a detection limit of approximately $1 \mathrm{ppm} .{ }^{70} \mathrm{It}$ is a nearly non-destructive method suitable for sensitive archaeological materials. ${ }^{71}$ In all cases, it has to be ensured that the samples are not affected by chemical alteration (i.e. patination) which would distort the results significantly.

\section{Terminological Issues: Characterisation of Raw Materials within the Chert Group}

Comparisons of different terminological approaches from western, central and eastern European scientists provided detailed insight into congruencies as well as disparities when defining $\mathrm{SiO}_{2}$ modifications. ${ }^{72}$ Inherently different approaches to this complex issue inevitably lead to misunderstandings. Thus, a commonly accepted working foundation requires a generally applicable terminology for the determination of such lithic resources within a classification system based on petrological, mineralogical and archaeological demands. An overview of lithic materials used for knapped stone tools is provided in Tab. 1, with members of the Chert Group highlighted.

These fundamental definitions circumscribe the study field and allow for representatives of the Chert Group to be discussed in detail. The continuation of the use of "popular names" for $\mathrm{SiO}_{2}$ modifications is one of the reasons for terminological misunderstandings and why some researchers call for a retreat to safe ground by addressing all siliceous sedimentary rocks as "silicites". With that in mind a consensual characterisation of these rock varieties is provided here in order to clarify the nomenclature for frequently used silicite types.

69 E.g. Brandl et al. 2011. - BrandL et al. 2013.

$701 \mathrm{ppm}$ corresponds to $0.1 \mathrm{wt} . \%=1000 \mathrm{~g} / \mathrm{t}$ in rock material.

71 For a detailed discussion concerning silicite provenance studies see BRANDL et al. 2011, 61-62.

72 E.g. Biró et al. 2000. - Affolter 2002. - Přichystal 2013. 
Tab. 1. Raw materials utilised for the production of chipped stone tools. Members of the Chert Group are highlighted (Graph: M. Brandl).

\begin{tabular}{|c|c|c|c|c|c|c|}
\hline & \multirow{2}{*}{$\begin{array}{c}\text { Material } \\
\text { quartz }\end{array}$} & \multirow{2}{*}{\begin{tabular}{|l} 
Name \\
historic
\end{tabular}} & \multirow{2}{*}{$\begin{array}{l}\text { Type } \\
\text { mineral }\end{array}$} & \multirow{2}{*}{$\begin{array}{c}\begin{array}{c}\text { Petrological } \\
\text { genesis }\end{array} \\
\text { primary igneous; } \\
\text { can have } \\
\text { metamorphic or } \\
\text { sedimentary origin } \\
\text { as well }\end{array}$} & \multirow{2}{*}{$\begin{array}{c}\text { Structure } \\
\\
\text { mono - } \\
\text { cryptocrystalline }\end{array}$} & \multirow{2}{*}{$\begin{array}{c}\text { Genesis } \\
\\
\text { inorganic }\end{array}$} \\
\hline & & & & & & \\
\hline & chalcedony & historic & mineral & $\begin{array}{l}\text { chemical precipita- } \\
\text { tion, hydrothermal }\end{array}$ & cryptocrystalline & inorganic \\
\hline & jasper & historic & mineral & $\begin{array}{l}\text { chemical precipita- } \\
\text { tion, hydrothermal }\end{array}$ & cryptocrystalline & inorganic \\
\hline & agate & historic & mineral & hydrothermal & cryptocrystalline & inorganic \\
\hline \multirow{9}{*}{ Chert Group } & flint & historic & rock & sedimentary & $\begin{array}{l}\text { crypto - micro- } \\
\text { crystalline }\end{array}$ & organic \\
\hline & chert & $\begin{array}{l}\text { depending on } \\
\text { fossil content }\end{array}$ & rock & sedimentary & $\begin{array}{l}\text { crypto - micro- } \\
\text { crystalline }\end{array}$ & organic \\
\hline & $\begin{array}{l}\text { silicified } \\
\text { limestone }\end{array}$ & $\begin{array}{l}\text { according to } \\
\text { the rock } \\
\text { consistence }\end{array}$ & rock & sedimentary & fine-crystalline & organic \\
\hline & lydite & historic & rock & $\begin{array}{c}\text { sedimentary } \\
\text { (sometimes } \\
\text { slightly } \\
\text { metamorphic) }\end{array}$ & fine-crystalline & $\begin{array}{l}\text { mainly } \\
\text { organic }\end{array}$ \\
\hline & opal & historic & mineral & $\begin{array}{l}\text { metamorphic, } \\
\text { sedimentary or } \\
\text { hydrothermal }\end{array}$ & $\begin{array}{l}\text { amorphous, par- } \\
\text { tially crystalline }\end{array}$ & $\begin{array}{c}\text { inorganic / } \\
\text { organic }\end{array}$ \\
\hline & $\begin{array}{l}\text { petrified } \\
\text { wood }\end{array}$ & $\begin{array}{l}\text { after source } \\
\text { material }\end{array}$ & $\begin{array}{l}\text { mineral } \\
\text { (if petrified } \\
\text { by quartz or } \\
\text { opal) }\end{array}$ & pseudomorphosis & $\begin{array}{l}\text { depending on pet- } \\
\text { rifying material }\end{array}$ & $\begin{array}{c}\text { inorganic / } \\
\text { organic }\end{array}$ \\
\hline & obsidian & $\begin{array}{l}\text { historic name } \\
\text { of a person } \\
\text { (Obsius) }\end{array}$ & igneous glass & igneous & $\begin{array}{l}\text { amorphous, rarely } \\
\text { partly crystalline }\end{array}$ & inorganic \\
\hline & tektite & after event & natural glass & $\begin{array}{l}\text { impact of a } \\
\text { meteorite }\end{array}$ & amorphous & inorganic \\
\hline & quartzite & $\begin{array}{l}\text { after source } \\
\text { material }\end{array}$ & rock & $\begin{array}{c}\text { sedimentary } \\
\text { (orthoquartzite) or } \\
\text { metamorphic } \\
\text { (metaquartzite) }\end{array}$ & $\begin{array}{l}\text { rough- fine- } \\
\text { crystalline }\end{array}$ & inorganic \\
\hline
\end{tabular}




\subsection{Chert}

Every sedimentary $\mathrm{SiO}_{2}$ rock (siliceous rocks, silicites) formed by biochemical processes can be referred to as "chert" sensu lato (see above). Accordingly, the rock matrix is primarily built from fossilised microorganisms, cemented by crypto- or microcrystalline quartz. In other cases the matrix can also be built up from calcareous mud or clay. Geologically, cherts occur during the Proterozoic, Palaeozoic, Triassic, Jurssic, Cretaceous and the Neogene period. Generally, the Chert Group can be divided into marine and lacustrine silicites. Within the marine chert varieties a specific sub-type is referred to as "flint" (discussion see below).

Fossil inclusions contained in the silicified chert matrix can be employed to define chert more precisely. Dominating microfossils are used to define subvarieties within the Chert Group, such as radiolarite, spiculite or spongiolite. However, a clear definition of these chert varieties is still lacking due to diverse research traditions in central and east European countries. Typically, the percentage of fossil inclusions visible under the stereomicroscope is used as the determining criterion. Depending on the scientific background, researchers define these chert varieties at inclusion ratios between 30 and $70 \%$ microfossils of one kind. This evolves into a problem when comparing raw material statistics of lithic assemblages on a broader, international scale.

Additionally, fossil inclusions are not uniformly dispersed in chert deposits. Typically, fossils occur concentrated in particular areas of chert banks or within nodules, whereas they can be absent in other parts of the same formation. It has been observed that microfossils in chert nodules tend to be accumulated towards the cortex area. Therefore, it has been proposed to define chert varieties according to an index fossil, i.e. the prevailing kind of microfossil (e.g. radiolaria, spicules, sponge remains), without guessing percentages. ${ }^{73}$ This has to be accompanied by the additional characterisation of the genesis environment and the technical properties (which the classification system is based upon) of the raw materials.

\subsection{Flint}

One specific member of the Chert Group is "flint", an especially critical term. Widely used throughout the literature, it was interchangeably applied to a variety of $\mathrm{SiO}_{2}$ raw materials. Common names generally refer to either of three possible attributes of raw materials referred to as "flint", the macroscopic appearance (e.g. Black flint), the geographical region (e.g. Baltic flint) or the geological age (e.g.

73 BRANDL 2010, 185
Danian flint). Thus, the term "flint" deserves special attention.

Recently there is a tendency "to use the term flint only for nodular siliceous rocks of the Upper Cretaceous Maastrichtian (and may be also of Lowermost Tertiary Danian) age coming from chalk formations or similar limestones". ${ }^{74}$ However, this only solves part of a larger problem. Regarding the wide use of the term "flint" it seems necessary to create a logical framework within which this term can be handled. The following parameters may help to clarify the situation:

(1) Spatial frame: The occurrence of "flint" is broadly confined to Europe north of the Alps and especially to northern Europe, with flint bearing formations extending from France to the Ukrainian territory.

(2) Timeframe: "Flint" is strictly bound to Cretaceous chalk sediments. As stated above, one position is to limit flint exclusively to Maastrichtian and Danian chalk formations. However, this seems too restrictive, since e.g. the Belgian Obourg or Nouvelles formations which are of Campanian age would then be excluded. Thus, a consensual solution would include the entire Upper Cretaceous stage (referred to as Senonian in the broader sense, encompassing all geological stages from the Cenomanian to the Danian).

(3) Genesis environment: Flint deposits are exclusively placed within chalk or similar limestone formations containing corresponding fossil faunal remains. ${ }^{75}$

(4) Consolidation: Bringing all defining parameters together, the geographical position, the host rock formations and fossil inclusions must correspond to parameters $1-3$.

As a conclusion, flint in the true sense is exclusively bound to cherts/silicites from northern European chalk formations. They have comparable fossil inclusions and formation environments, thus they can be subsumed under the term "flint". Taking into account that other $\mathrm{SiO}_{2}$ rocks of Cretaceous age exist besides the "sensu stricto flint", the term "Cretaceous chert (silicite)" is a compromise for such raw materials (e.g. the Cretaceous Southern Alpine deposits).

This being said, some general remarks concerning the attributes of silicites designated as "flint" are provided. Most commonly, flint occurs as irregularly shaped roundish or flat nodules. Flint fractures conchoidal and displays a smooth, satiny breakage surface. In most cases, there is no granularity recognisable due to the cryptocrystalline texture. Poorly silicified rock parts and inclusions can produce

74 Přichystal 2010, 179.

75 See Tab. 4. 
coarse areas in flint nodules though. Particularly flints of Maastrichtian and Danian age contain high amounts of fossil inclusions, affording a closer determination. Banded flint from north European sources is also referred to as "Falster". ${ }^{76}$ Compared to alpine cherts, flint formed in soft host rock (chalk environments) was less tectonically stressed and thus displays significantly less fissures and clefts.

\subsection{Siliceous limestone}

Genetically, siliceous limestone is closely related to chert, and both occur in the same geological contexts. This rock material is often a less silicified precursor of cherts, and typically alpine cherts contain certain amounts of silicified limestone. If very fine grained, a differentiation between the two can only be achieved applying some of the above mentioned basic testing methods.

(1) The scratch test with a steel needle produces different abrasion patterns in cases of poorly silicified material compared to chert sensu stricto.

(2) Applying diluted $\mathrm{HCl}$ (hydrochloric acid) is the most suitable method for a distinction. Siliceous limestone is still highly carbonatic, resulting in significant foaming effects when tested.

(3) Under the stereomicroscope, reflected light is scattered by calcite surfaces indicating the presence of carbonates.

\subsection{Lydite ("Flinty slate")}

Lydite is a layered silicite displaying a "slaty" structure and typically of Palaeozoic age. The colour is predominantly black, originating from organic inclusions. Sometimes it can be slightly metamorphic. Due to diagenetic effects, fossil inclusions are in most cases deformed or completely dissolved in the rock matrix. Thus, microfossil inclusions are barely detectable in lydite under the microscope.

\section{The Chert Group Classification System}

The framework of the classification system was developed at the Austrian Academy of Sciences in the course of the determination of the lithic assemblage from KremsHundssteig and Krems-Wachtberg. ${ }^{77}$ The high raw material variability detected in these Upper Palaeolithic sites initiated this systematic approach; the coherent version of the classification system was designed succeeding extended raw material studies in various projects. ${ }^{78}$

\footnotetext{
76 Elburg, van der Kroft 2014.

77 Brande, Reiter 2008, 43-49.

78 E.g. Brandi, Reiter 2008. - Brandl 2009. - Brandl et al. 2011. - BRANDL et al. 2013.
}

\subsection{Classification criteria}

The goal of every classification is to categorise items according to standardised "classes". Classification always depends on the current research question. If one aims at the systematic categorisation of the different phases of silica between amorphous and fully crystalline a system indicating distinct size limits of such "classes" has to be applied. However, if the measurement of biomass quantity contained in a silicite is the goal of the classification the classes will be defined according to percentages. Accordingly, it is necessary to indicate the criteria within a formalised determination system. The proposed and successfully tested classification system is based on technical properties of the raw materials. The criteria elucidate these technical properties of rocks within the Chert Group and aim at the reconstruction of an important component leading to the choice prehistoric people made when selecting raw materials for stone tool production: Their quality and usability.

\subsubsection{General criteria}

Every classification depends on the determination and description of properties characteristic for the object under discussion. In the case of silicites, these are petrographical determinants useful for the characterisation and differentiation of raw materials from established source areas. Some approaches use colour as a distinctive element, ${ }^{79}$ however, in the currently proposed classification it is not considered source specific and therefore not included into the general categories to be investigated.

\subsubsection{Granularity}

The grain size is commonly defined by ISO 14688-1-standards (Tab. 2). In the proposed Classification System, they range from very coarse to very fine grained. A higher resolution is generally not applicable and thus not useful for such a classification approach.

\subsubsection{Fissures}

Tectonic activity can cause cracking of rocks referred to as fissures or clefts. Especially alpine cherts imbedded in solid host rocks, e.g. limestone formations, are frequently tectonically stressed, thus displaying characteristic fissures. In most cases, these gaps are secondarily filled, either with (vein-) quartz or foreign minerals such as calcite (which leads to a characteristic "vein-structure").

\subsubsection{Carbonate content}

Typically, silicites originate from limestone or chalk formations, thus they can inherently contain carbonates.

79 E.g. McElrath, Emerson 2000. 
Tab. 2. Grain sizes of sediments adapted from BSI 2009 (Graph: M. Brandl).

\begin{tabular}{|c|c|c|c|c|}
\hline \multicolumn{4}{|c|}{ ISO 14688-1 according to BSI 2009} & \multirow{2}{*}{$\begin{array}{l}\text { Classification system for lithic } \\
\text { raw materials }\end{array}$} \\
\hline \multicolumn{3}{|c|}{ name } & size range & \\
\hline \multirow{3}{*}{ Coarse soil } & \multirow{3}{*}{ Sand } & Coarse sand, CSa & $>0.63-2.0 \mathrm{~mm}$ & \multirow{3}{*}{ (3) coarse grained } \\
\hline & & Medium sand, MSa & $>0.2-0.63 \mathrm{~mm}$ & \\
\hline & & Fine sand, FSa & $>0.063-0.2 \mathrm{~mm}$ & \\
\hline \multirow{4}{*}{ Fine soil } & \multirow{3}{*}{ Silt } & Coarse silt, CSi & $>0.02-0.063 \mathrm{~mm}$ & \multirow{2}{*}{ (2) medium grained } \\
\hline & & Medium silt, MSi & $>0.0063-0.02 \mathrm{~mm}$ & \\
\hline & & Fine silt, FSi & $>0.002-0.0063 \mathrm{~mm}$ & \multirow{2}{*}{ (1) fine grained } \\
\hline & \multicolumn{2}{|c|}{ Clay, Cl } & $\leq 0.002 \mathrm{~mm}$ & \\
\hline
\end{tabular}

Traces of calcite and/or dolomite are commonly found in cherts, however they rarely exceed $1 \mathrm{wt} . \%$ in the rock matrix and are not major rock constituents. ${ }^{80}$ As indicated above, calcite inclusions react with weak acids, e.g. deluted hydrochloric acid $(\mathrm{HCl})$, whereby escaping $\mathrm{CO}_{2}$ causes more or less visual foaming on the rock surface, depending on the carbonate content present in the sample. Oftentimes, carbonates are only detectable in the cortex areas of chert and flint.

\subsubsection{Matrix}

The composition of a rock including all rock-forming

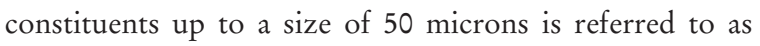
"matrix". For silicites from carbonatic host rocks, orthosilicic acid functions as the cementing material. According to Graetsch and Grünberg, who conducted long-term XRDanalyses on chert, flint and other microcrystalline $\mathrm{SiO}_{2}$ modifications, chalcedony is the predominant $\mathrm{SiO}_{2}$ variety in the rock matrix. ${ }^{81}$ Depending on factors like homogeneity and inclusions in the rock matrix, specimens display more or less fine granularity. In contrast to very fine grained Baltic flint, alpine silicites oftentimes illustrate a coarser granularity due to recrystallisation processes.

\subsubsection{Inclusions}

There exists a wide range of possible inclusions in silicites which can be superficially divided into fossil and nonfossil (biotic and abiotic). However, in some cases a clear determination is not possible due to the small size or the insignificant appearance of inclusions under the microscope, specifically in the case of diagenetically deformed, fractured or triturated fragments of microfossils as well as

80 Graetsch, Grünberg 2012, 34.

81 Graetsch, Grünberg 2012, 34. foreign minerals. As long as such inclusions can still be identified as organic, they are referred to as "detritus" (= particulate organic material, in short POM).$^{82}$

\section{Fossil inclusions}

Fossil inclusions can only occur in rocks, they never occur in minerals. Only sedimentary rocks contain fossil inclusions useful for a determination, they are barely preserved in metamorphic rocks and never present at magmatic rocks. Micropalaeontology is an especially important tool for the determination of biogenic rock materials. In marine sedimentary genesis environments, the following faunal remains are common and can be identified (depending on the preservation conditions).

\section{Radiolarians (Plate 1)}

Radiolarians are marine protozoans of the order radiolaria, displaying rigid siliceous skeletons and protruding pseudopodia. Radiolarians occur almost exclusively in the open ocean as part of the plankton community. Their skeletons abundantly occur in ocean sediments. Two important super-orders can be distinguished within the Radiolarian class: Triptylea and Polycystina. Only the latter form skeletons composed of pure opal. Therefore, they are more resistant to dissolution in seawater and typically found in the fossil record. Polycystina may again be divided into two suborders, the Spumellaria displaying a spheric shape and the Nasselaria with different, non-spheric shapes. ${ }^{83}$

\section{Foraminifera (Plate 2)}

Foraminifera ("hole bearers"), more accurately Foraminiferida, are single celled marine organisms producing a

82 Volkman, Tanoue 2002.

83 MIRACLE 2014 
test or shell either from calcium carbonate $\left(\mathrm{CaCO}_{3}\right)$ or agglutinated sediment particles. Their shells possess one or multiple chambers of sometimes elaborate structure. Foraminifera can occur as benthic (at the sea bottom) or planktic (in the upper zones of the ocean). In the microfossil record of silicites, Foram tests are characteristic for siliceous rocks formed in Cretaceous sediments ${ }^{84}$ as well as for Triassic and Jurassic layers occurring at the foothills of the Schwarzwald and throughout the entire Jura Mountains, and the Swabian and Franconian Albs.

\section{Marine sponges (Plate 3)}

The majority of spongial remains detected in rocks of the chert family are members of the class Demospongiae (phylum Porifera). There exist three main variations: (1) Sponge skeletons consisting of spongin fibers, a protein, and spicules ("skeletal needles"); (2) some sponges consist entirely of spongin, and (3) others only have spicules. The spongin acts as the binding tissue for the spicules; if there are no spicules present the skeleton is articulated with very dense fibres of spongin. Sponge remains occur in cherts in every possible stage of preservation, from complete organisms to disintegrated body parts (e.g. in Craców "flint") down to single spicules. ${ }^{85}$

Spicules (Plates $3 / 3$ and 4 ) are important skeletal elements of various marine and freshwater invertebrates. Contained in chert, spicules predominantly represent skeletal needles originating from marine sponges (Demospongiae), consisting of silica. The most common varieties are the following: Monaxons are spicules with one single axis. They comprise monactinal and diactinal spicules. Monactinal spicules are acicular and pointed at one end, the other end is rounded, diactinal monaxons display two pointed ends. Three-axial spicules are referred to as triaxons, and spicules constituting four needle elements are called tetraxons. ${ }^{86}$ However, Northern (kalk-) Alpine cherts mainly contain monaxon spicules, whereas polyaxons (more than 2 pointed ends) are characteristic for non-alpine silicites, e.g. Carpathian silicites or (Baltic) flint. ${ }^{87}$

\section{Echinodermata (Plates 4; 5)}

Echinoderms encompass a large group of marine creatures, predominantly inhabiting the floors of flat ocean areas. As a rule all echinoderms display symmetry of the $5^{\text {th }}$ order. There exist two main variations within the echinoderms, some are attached to a substrate and others are

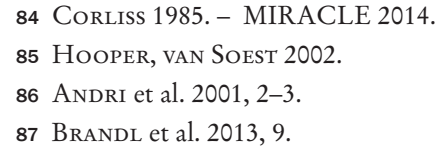

mobile. Due to their importance in the chert and flint microfossil record, two species are discussed in detail.

Sea urchins (Plate 4) constitute the class Echinoidea within the Echinodermata phylum. They have a shell from calcium carbonate protected by long characteristic spines. Sea urchin spines or parts of the endoskeleton are also frequently observed in silicites. Predominantly they occur in Cretaceous siliceous rock formations. In rarer cases, the entire endoskeleton can be "chertified".

Crinoids (Plate 5) are marine organisms also known as "sea lilies" or "feather-stars". They constitute the class Crinoidea within the phylum Echinodermata. Their habitat can be both shallow water and deep sea environments. Typically, crinoids have a horizontal mouth opening on the top of the animals head, surrounded by multiple feeding arms. In most cases, crinoids are attached to solid ground with a stem; however, there occur stemless specimens as well. ${ }^{88}$ In the silicite fossil content, the joints of crinoid stems, so-called "trochites", are the most frequently preserved remains of these organisms. Trochites are recognisable by their rectangular cross section in chert and flint. When fractured, trochites display a shiny surface corresponding to the crystalline cleavage of a calcite monocrystal. ${ }^{89}$

\section{Additional fossil inclusions (Plate 6)}

Besides the above described, numerous additional fossil inclusions can be observed in silicites. These involve bryozoa, diatoms, skeleton elements of various marine organisms, seashells, algae, pellets (roundish shaped grains consisting of carbonate mud) and unidentifiable detritus as the commonest amongst an endless list of possible fossil remains in marine $\mathrm{SiO}_{2}$ raw materials. For some of the less frequent species, especially when heavily damaged, professional micropalaeontologists should be consulted.

\section{Non-fossil inclusions (Plate 7)}

The most abundant non-fossil inclusions in silicites are heavy minerals like garnet, tourmaline, rutile, ilmenite, cassiterite, etc. Mica is also a common element in specific chert deposits. However, an accurate determination of such foreign mineral inclusions requires mineralogical/geochemical analysis. Intraclasts, foreign lithic fragments or grains embedded in carbonatic sediments in the course of fragmentation, transport and deposition, are also characteristic features of certain silicites.

It is a commonly observed phenomenon with silicites that quartz accumulates in the form of sometimes colourful

88 Moore, Laudon 1943. - The Paleontological Society 2014. 89 Tegethoff et al. 2001, 328. 
Tab. 3. Classification table for members of the Chert Group I: Chert (Graph: M. Brandl).

\begin{tabular}{|l|l|l|l|}
\hline \multicolumn{2}{|l|}{ Genesis } & \multicolumn{2}{|c|}{ Precambrian - Neogene age } \\
\hline \multirow{2}{*}{ Fissures } & yes & often & \\
\cline { 2 - 3 } & no & rarely & \\
\hline \multirow{2}{*}{ Fracture properties } & conchoidal-smooth & \\
\cline { 3 - 3 } & amorphously-rough & \\
\hline \multirow{2}{*}{ Granularity } & very coarse- to very fine-grained & \\
\hline $\begin{array}{l}\text { Carbonate } \\
\text { content }\end{array}$ & yes & not always detectable & \multirow{2}{*}{ siliceous limestone } \\
\hline
\end{tabular}

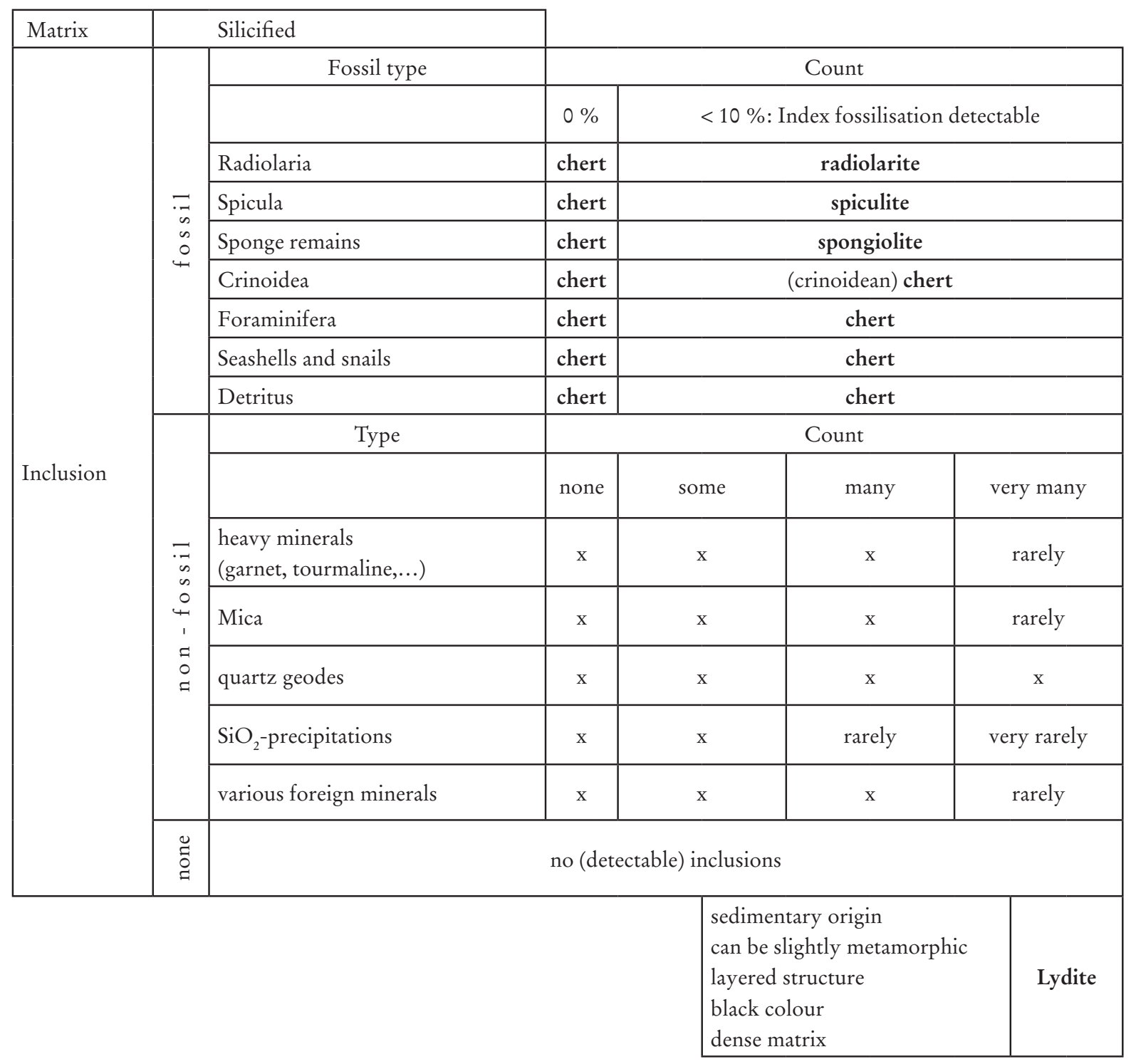


Tab. 4. Classification table for members of the Chert Group II: Flint (Graph: M. Brandl).

\begin{tabular}{|c|c|c|c|c|c|c|}
\hline \multicolumn{3}{|r|}{ Upper Cretaceous } & & & & \\
\hline \multirow{2}{*}{ Fissures } & yes & rarely & & & & \\
\hline & no & often & & & & \\
\hline \multicolumn{2}{|c|}{ Fracture properties } & conchoidal-smooth & & & & \\
\hline \multicolumn{2}{|l|}{ Granularity } & very fine grained & & & & \\
\hline \multirow{2}{*}{$\begin{array}{l}\text { Carbonate } \\
\text { content }\end{array}$} & yes & in the cortex & & & & \\
\hline & no & in the matrix & & & & \\
\hline \multicolumn{2}{|l|}{ Matrix } & very densly silicified & & & & \\
\hline \multirow{17}{*}{ Inclusions } & \multirow{9}{*}{$\begin{array}{l}= \\
\text { s } \\
\text { s } \\
0 \\
+\end{array}$} & Fossil type & \multicolumn{4}{|c|}{ Count } \\
\hline & & & $0 \%$ & & & very many \\
\hline & & A.a Radiolaria & always & \multicolumn{3}{|c|}{ never } \\
\hline & & A.b Spicula & rarely & \multicolumn{2}{|c|}{ often } & $\begin{array}{l}\text { possible - } \\
\text { rarely }\end{array}$ \\
\hline & & A.c Sponge remains & rarely & \multicolumn{2}{|c|}{ often } & $\begin{array}{c}\text { possible - } \\
\text { rarely }\end{array}$ \\
\hline & & A.d Crinoidea & often & \multicolumn{2}{|c|}{ possible } & $\begin{array}{l}\text { possible - } \\
\text { rarely }\end{array}$ \\
\hline & & A.e Foraminifera & often & \multicolumn{2}{|c|}{ possible - often } & $\begin{array}{l}\text { possible - } \\
\text { rarely }\end{array}$ \\
\hline & & A.f Seashells & possible & \multicolumn{2}{|c|}{ possible - rarely } & $\begin{array}{l}\text { possible - } \\
\text { rarely }\end{array}$ \\
\hline & & A.g Detritus & & \multicolumn{2}{|l|}{ often } & $\begin{array}{c}\text { possible - } \\
\text { rarely }\end{array}$ \\
\hline & \multirow{7}{*}{$\begin{array}{l}= \\
0 \\
0 \\
0 \\
+ \\
1 \\
\overrightarrow{1} \\
0 \\
=\end{array}$} & Type & \multicolumn{4}{|c|}{ Count } \\
\hline & & & none & some & many & very many \\
\hline & & \begin{tabular}{|l|} 
A.a. Heavy minerals \\
(garnett, tourmaline, ...)
\end{tabular} & always & never & never & never \\
\hline & & A.b. Mica & always & never & never & never \\
\hline & & A.c. Quartz geodes & possilbe & possible & rarely & rarely \\
\hline & & A.d. $\mathrm{SiO}_{2}$-precipitations & often & often & possible & possible \\
\hline & & A.e. Various foreign minerals & possible & rarely & very rarely & very rarely \\
\hline & $\begin{array}{l}\mathscr{\Xi} \\
\stackrel{0}{0}\end{array}$ & \multicolumn{5}{|c|}{ no inclusions } \\
\hline
\end{tabular}


$\mathrm{SiO}_{2}$-precipitations during primary chert formation. Fissures and cracks in chert are oftentimes secondarily filled with carbonates or quartz. Depending on the geological conditions, cracks can display geodes containing rock crystals or they are entirely filled with chalcedony. ${ }^{90}$

\subsubsection{Fracture properties}

Different raw materials display diverse breaking effects; however they are not necessarily equitable with their knapping properties. "Fracture properties" refer to breaking schemes in general rather than only those deriving from intentional knapping, although in many cases they definitely coincide. Typically, rocks within the Chert Group fracture conchoidal-smooth in the case of fine-grained varieties and amorphously-rough when coarse-grained.

\subsubsection{Knapping properties}

From an archaeological point of view, the knapping properties of lithic raw materials are of main significance. Knapping properties are influenced by all criteria defined above to different degrees and always contingent on the fracture properties, but not vice versa. They are directly linked to and thus a crucial factor for determining the "quality" of lithic raw materials used for chipped stone tool production, which is predominantly depending on the homogeneity (=lack of fissures), the granularity and the inclusions present.

\subsection{Practical application of the Chert Group Classification System (CGCS)}

The CGCS is the result of the implications outlined above and designed as a research tool for archaeologists working with lithic assemblages. The categories defined under section 9.1 (Classification criteria) are detailed in Tabs. 3 and 4. The classification is designed in the form of a multiple choice system, in which the highest accordance of traits observed on a specific silicite affords an unambiguous determination and assignment to clearly defined sedimentary, biogenic $\mathrm{SiO}_{2}$ modifications. It is not claimed here that every problematic $\mathrm{SiO}_{2}$ rock can securely be determined applying the CGCS, however, practical application at the Austrian Academy of Sciences has demonstrated its suitability for the task of identifying $\mathrm{SiO}_{2}$ rocks from the Chert Group from an archaeological context.

\section{Acknowledgements}

I want to thank Ing. Walter Brandl, who provided invaluable help in the course of the development of the CGCS and contributed significantly to the structure of the classification system. Comments from the two anonymous reviewers were highly appreciated and considered. I specifically want to thank Jehanne Affolter for her comments and suggestions.

\section{Literature}

AcKerman 1964

R. E. Ackerman, Lichens and the patination of chert in Alaska, American Antiquity 29/3, 1964, 386-387.

\section{AfFOlTER 2002}

J. Affolter, Provenance des silex préhistoriques du Jura et des régions limitrophes, Archéologie Neuchâteloise 28/1, Neuchâtel 2002.

Altdorfer, Affolter 2011

K. Altorfer, J. Affolter, Schaffhauser Silex-Vorkommen und Nutzung. Beiträge zur Schaffhauser Archäologie 5, Schaffhausen 2011.

ANDRI et al. 2001

E. Andri, S. Gerbaudo, M. Testa, Quaternary siliceous sponge spicules in the Western Woodlark Basin, Southwest Pacific (ODP Leg 180). In: P. Huchon, B. TAYLOR, A. Klaus (Eds.), Proceedings of the Ocean Drilling Program, Scientific Results 180, 2001, 1-8. http:// www-odp.tamu.edu/publications/180_SR/153/153. htm (last access 1.11.2014).

BECHTER et al. 2010

D. Bechter, P. Tropper, R. Kaindl, W Leitner, B. Nutz, Mikro-Ramanspektrometrische Untersuchungen von ost- und südalpinem Silex (Gemsteltal/Walsertal, Antonshöhe bei Mauer, Österreich; Val di Non, Trentino, Italien), Mitteilungen der Österreichischen Mineralogischen Gesellschaft 156, 2010, 23-35.

Biró 2010

K. T. Biró, Terminological practice for siliceous rocks in Hungary from petroarchaeological point of view, Archeometriai Múhely 2010/3, 195-202.

Biró et al. 2000

K. T. Biró, V. Dobosi, Z. Schléder, Lithotheca II: Comparative Raw Material Collection of the Hungarian National Museum II. Budapest 2000.

Boggs 2009

S. Boggs Jr., Petrology of Sedimentary Rocks. Second edition. New York 2009.

BRANDL, REITER 2008

M. BrandL, V. Reiter, Erstellung einer Rohmaterialdatenbank auf Grundlage der Silexfunde der Paläolithstationen von Krems - Hundssteig und Krems - Wachtberg, Archäologie Österreichs 19/1 2008, 43-49. 
BRANDL 2009

M. Brande, Silexlagerstätten in der Steiermark. Mitteilungen der Prähistorischen Kommission der Österreichischen Akademie der Wissenschaften 69, Vienna 2009.

BRANDL 2010

M. Brand, Classification of rocks within the Chert Group: Austrian practice, Archeometriai Múhely 2010/3, 183-190.

BRANDL et al. 2011

M. Brandl, C. Hauzenberger, W. Postl, D. Modl, C. Kurta, G. Trnka, Repolust Cave (Austria) revisited: provenance studies of the chert finds, Quartär 58, 2011, $51-65$.

BRANDL et al. 2013

M. Brandl, C. Hauzenberger, W. Postl, M. M. MartineZ, P. Filzmoser, G. Trnka, Radiolarite studies at Krems-Wachtberg (Lower Austria) - northern Alpine vs. Carpathian lithic resources, Quaternary International 2013. doi: 10.1016/j.quaint.2013.01.031.

BRANDL et al. in press

M. Brandl, L. Moreau, O. Schmitsberger, C. NeugeBaUer-Maresch, The southern Moravian cherts at the Aurignacian site of Stratzing-Galgenberg, Austria, International Journal of Human Diversity and Evolution, Special Issue Karel Valoch (Guest Eds. M. GALEtová, A. Bilsborough), in press.

BURRonia et al. 2002

D. Burronia, R. E. Donahuea, A. M. Pollarda, M. Mussib, The surface alteration features of flint artefacts as a record of environmental processes, Journal of Archaeological Science 29/11, 2002, 1277-1287.

Calvert 1974

S. E. CAlvert, Deposition and diagenesis of silica in marine sediments. In: K. F. Hsü, H. C. Jenkyns (Eds.), Pelagic Sediments: On Land and Under the Sea. Special Publication of the International Association of Sedimentology 1, Oxford 1974, 273-299.

CORLISS 1985

B. H. Corliss, Microhabitats of benthic foraminifera within deep-sea sediments, Nature 314, 1985, 435-438.

Dubicka, Peryt 2012

Z. Dubicka, D. Peryt, Foraminifers and stable isotope record of the Dubivtsi chalk (upper Turonian, Western Ukraine): palaeoenvironmental implications, Geology Quarterly 56/1, 2012, 199-214.

Elburg, van der Kroft 2014

R. Elburg and P. van der Kroft, Flintsource.net, http:// www.flintsource.net/flint/DK_hasselo.html (last access 4.4.2014).
FAure 1998

G. Faure, Principles and Applications of Geochemistry. Second edition, Prentice Hall 1998.

Frondel 1962

C. Frondel, The System of Mineralogy 3. New York 1962. Graetsch, Grünberg 2012

H. A. Graetsch, J. M. Grünberg, Microstructure of flint and other chert raw materials, Archaeometry 54/1, 2012, 18-36.

GÖTZE 2010

J. GöTZE, Origin, mineralogy, nomenclature and provenance of silica and $\mathrm{SiO}_{2}$ rocks, Archeometriai Múhely 2010/3, 163-176.

Hein, Obradović 1989

J. R. Hein and J. Obradović, Siliceous deposits of the Tethys and Pacific regions. In: J. R. Hein, J. Obradović (Eds.), Siliceous Deposits of the Tethys and Pacific Regions. Berlin, 1989, 1-17.

HoOper, van SOEST 2002

J. N. Hooper, R. W. van Soest (Eds.), Systema Porifera: A Guide to the Classification of Sponges. New York 2002.

Houser 1985

B. B. Houser, Magadi-type chert, indicator of a lacustrine environment in the Middle Eocene McBean formation, South Carolina, Southeastern Geology 25, 1985, 185197.

HOWARD 2002

C. D. Howard, The gloss patination of flint artifacts, Plains Anthropologist 2002/1, 283-287.

Knauth, Lowe 2003

P. Knauth, D. R. Lowe, High Archean climatic temperature inferred from oxygen isotope geochemistry of chert in the 3.5 Ga Swaziland Supergroup, South Africa, Geological Society of America Bulletin 115/5, 2003, 566-580.

LASCHET 1984

C. Laschet, On the origin of cherts, Facies 10/1, 1984, 257-289.

LUEDTKE 1992

B. E. Luedtke, An Archaeologist's Guide to Chert and Flint. Archaeological Research Tools 7, Los Angeles 1992.

LUKASHINA 2006

N. P. Lukashina, Paleogeography of the southern Baltic region in the Late Mesozoic: implications of Foraminifers, Stratigraphy and Geological Correlation14/3, 2006, 283-301. 
McCann 2008

T. McCann (Ed.), The Geology of Central Europe, Volume 2: Mesozoic and Cenozoic. Geological Society, London 2008.

McElrath, Emerson 2000

D. L. McElrath, T. E. Emerson, Toward an "intrinsic characteristics" approach to chert raw material classification: an American bottom example, Midcontinental Journal of Archaeology 25/2, Papers in Honor of James B. Stoltman, Fall 2000, 215-244.

MeL'NYK 1982

Y. P. MeL'NYK, Precambrian Banded Iron Formations: Physiochemical Conditions of Formation. Developments in Precambrian Geology 5, Amsterdam 1982.

Micheelsen 1966

H. Micheelsen, The structure of dark flint from Stevns, Denmark, Dansk Geologisk Forening 16, 1966, 286368.

Milliken 2003

K. L. Milliken, Diagenesis. In: G. V. Middleton (Ed.), Encyclopedia of Sediments and Sedimentary Rocks, Dordrecht - Boston - London 2003, 214-218.

MIRACLE 2014

MIRACLE. Microfossil image recovery and circulation for learning and education. University College London, Micropalaeontology Unit. http://www.ucl.ac.uk/ GeolSci/micropal/index.html (last access 4.4.2014).

Moore, Laudon 1943

R. C. Moore, L. R. Laudon, Evolution and classification of Paleozoic crinoids, Geological Society of America Special Papers 46, 1943, 1-158.

Murata, Larson 1975

K. J. Murata, R. R. Larson, Diagenesis of Miocene silicieous shale, Temblor Range, California, U.S. Geological Survey Journal of Research, 3, 1975, 553-566.

Murray 1994

R. W. Murray, Chemical criteria to identify the depositional environment of Chert: General principles and applications, Sedimentary Geology 90, 1994, 213-232.

Muttoni, Kent 2007

G. Muttoni, D. V. Kent, Widespread formation of cherts during the early Eocene climat optimum, Palaeogeography, Palaeoclimatology, Palaeoecology 253, 2007, 348-362.

Ozsvárt 2008

P. Ozsvárt, Radiolarites in the Carpathian Basin: occurences, types and ages. Paper presented at Archeometriai Múhely - Kora-neolitikumi közösségek kőeszközeinek archeometriai vizsgálata Prompt Gamma Aktivációs Analízissel - különös tekintettel a radiolaritokra és obszidiánokra, Budapest 2008.
Perry, Lefticariu 2003

E. C. Perry and L. Lefticariu, Formation and geochemistry of Precambrian cherts, Treatise on Geochemistry 7, 2003, 99-113.

Pisciotтo 1980

K. A. Pisciotтo, Chert and porcellanite from Deep Sea Drilling Project Site 43, northwest Pacific. In Scientific Party, Deep Sea Drilling Project Initial Reports 56, 57/ 2. U.S. Government Printing Office, Washington, 1980, 1133-1142.

Pienkowski et al. 2008

G. Pienkowski, M. E. Schudack, P. Bosák, R. Enay, A. Feldman-Olszewska, J. Golonka, J. Gutowski, G. F. W. Herngreen, P. Jordan, M. Krobicki, B. Lathuiliere, R. R. Leinfelder, J. Michalik, E. Mönnig, N. Noe-Nygaad, J. Pálfy, A. Pint, M. W. Rasser, A. G. Reisdorf, D. U. Schmid, G. Schweigert, F. Surlyk, A. Wetzel, T. E. Wong, Jurassic. In: McCann 2008, 823-922.

Přichystal 2010

A. Přichystal, Classification of lithic raw materials used for prehistoric chipped artefacts in general and siliceous sediments (silicites) in particular: the Czech proposal, Archeometriai Múhely 2010/3, 177-182.

Přichystal 2013

A. Přichystal, Lithic Raw Materials in Prehistoric Times of Eastern Central Europe. Brno 2013.

Remicourt et al. 2009

M. Remicourt, J. Vaquer, M. Bordreuil, Production et diffusion au Chalcolithique des lames en silex du Ludien de Collorgues (Gard), Gallia Préhistoire, 2009/51, 213-244.

ROTTLÄNDER 1975

R. C. A. Rottländer, The formation of patina on flint, Archaeometry 17/1, 1975, 106-110.

ROTTLÄNDER 1983

R. C. A RotTländer, Einführung in die naturwissenschaftlichen Methoden in der Archäologie. Archaeologica Venatoria 6. Tübingen 1983.

RotTLÄNDER, Weymouth 1980/1981

R. C. A. Rottländer, J. W. Weymouth, Über das Ionenaustauschverhalten von Feuersteinen (On the exchange of ions of flint), Acta Praehistorica et Archaeologica 11/12, 1980/1981, 35-36.

Scheck-Wenderoth, Lamarche 2005

M. Scheck-Wenderoth, J. Lamarche, Crustal memory and basin evolution in the Central European Basin System-new insights from a 3D structural model, Tectonophysics 397/1, 143-165. 
SCHECK-Wenderoth et al. 2008

M. Scheck-Wenderoth, P. Krzywiez, R. Zühlke, Y. Maystrenko, N. Froitzheim, Permian to Cretaceous tectonics. In: McCann 2008, 999-1030.

SCHMALZ 1960

R. F. Schmalz, Flint and the patination of flint, Proceedings of the Prehistoric Society 26, 1960, 44-49.

Sugitani et al. 2002

K. Sugitani, K. Yamamoto, H. W. Wada, S. S. Binu-Lal AND M. Yoneshig, Geochemistry of Archean carbonaceous cherts deposited at immature island-arc setting in the Pilbara Block, Western Australia, Sedimentary Geology 151/1-2, 2002, 45-66.

Tegethoff 2001

F.W. Tegethoff (ed.), Calcium carbonate: from the Cretaceous period into the 21 st century. In collab. with J. Rohleder and E. Kroker. Basel - Boston - Berlin 2001.

The Paleontological Society 2014

The Paleontological Society, Crinoids, www.paleosoc.org/Crinoids.pdf (last access 2.11.2014).

Tollmann 1984

A. Tollmann, Entstehung und früher Werdegang der Tethys mit besonderer Berücksichtigung des mediterranen Raumes, Mitteilungen der österreichischen geologischen Gesellschaft 77, 1984, 93-113.

UMEDA 2003

M. Umeda, Precipitation of silica and formation of chertmudstone-peat association in Miocene coastal environments at the opening of the Sea of Japan, Sedimentary Geology 16/3-3, 2003, 249-268.

VAN DER VOO 1993

R. VAn Der Voo, Paleomagnetism of the Atlantic, Tethys and Iapetus Oceans. Cambridge 1993.

Volkman, Tanoue 2002

J.K. Volkman, E. Tanoue, Chemical and biological studies of particulate organic matter in the ocean, Journal of Oceanography 58, 2002, 265-279.
Voigt et al. 2008

S. Voigt, M. Wagreich, F. Surlyk, I. Walaszczyk, D. UlicnÝ, S. Cech, T. Voigt, F. Wiese, M. Wilmsen, B. Niebuhr, M. Reich, H. Funk, J. Michalik, J.W.M. Jagt, P.J. Felder, A.S. Schulp, Cretaceous. In: McCann 2008, 923-998.

VON RAD 1974

U. Von Rad, $\mathrm{SiO}_{2}$-Diagenese in Tiefseesedimenten, Geologische Rundschau 68, 1974, 1025-1036.

Weiss-Krejci, Brandl 2011

E. Weiss-Krejci, M. BrandL, Research at La Milpa East (RB LME) and the Aguada Lagunita Elusiva (RB Lagunita): The 2010 Season. In: B. A. Houk, F. VAldeZ Jr. (Eds.), Occasional Papers 12, Mesoamerican Archaeological Research Laboratory (MARL), Research Reports from the Programme for Belize Archaeological Project, Austin, 2011, 143-169.

Westall et al. 2006

F. Westall, S. T. de Vries, W. Nijman, V. Rouchon, B. Orberger, V. Pearson, J. Watson, A. Verchovsky, I. Wright, J.N. Rouzard, D. Marchesini, A. SeverINE, The 3.466 Ga "Kitty's Gap Chert", an early Archean microbial ecosystem, GSA Special Papers 405, 2006, 105-131.

Michael Brandl

Institute for Oriental and European Archaeology (OREA) Austrian Academy of Sciences

Fleischmarkt 22

1010 Vienna

Austria

michael.brandl@assoc.oeaw.ac.at 


\section{Radiolarians}
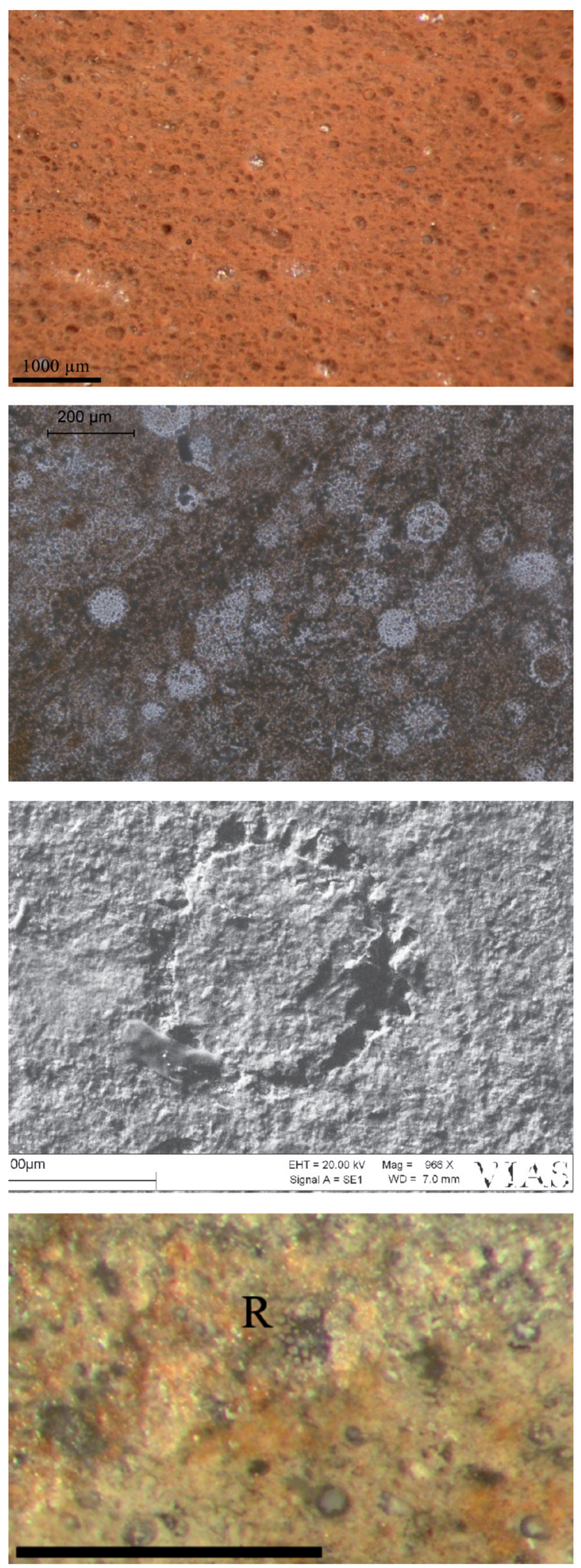

Plate 1

\section{Radiolarite. Vienna Mauer, Austria.}

St Veit Klippen Belt, Upper Jurassic.

Re-crystallised radiolarian skeletons are sometimes filled with chalcedony or moganite (bluish-grey) and sometimes with a calcite monocrystal.

Unpolished surface. $40 \times$ magnification. Water immersion.

(Microphoto: M. Brandl).

2. Radiolarite. Grubalacke source. Rofan Mountains, northern Tyrol, Austria.

Ruhpolding Formation, Lower-Middle Jurassic.

Cross sections of radiolarians.

Polished surface. Thin section.

(Microphoto: M. Brandl).

3. Radiolarite. Grubalacke source (see No. 2).

Surface structure of a radiolarian. The less silicified pseudopodia surrounding the inner part of the radiolarian are weathered and therefore visible as negative imprints.

Environmental SEM image. Unpolished surface. (Photo: M. Mehofer, VIAS).

4. Radiolarite. Danube river gravels near Krems, Austria.

Northern Calcareous Alps, Jurassic.

Detailed micropicture of a weathered radiolarian with visible surface pore structure (R).

Unpolished surface. Lenght of the bar: $1 \mathrm{~mm}$. (Microphoto: M. Brandl). 
Foraminifers

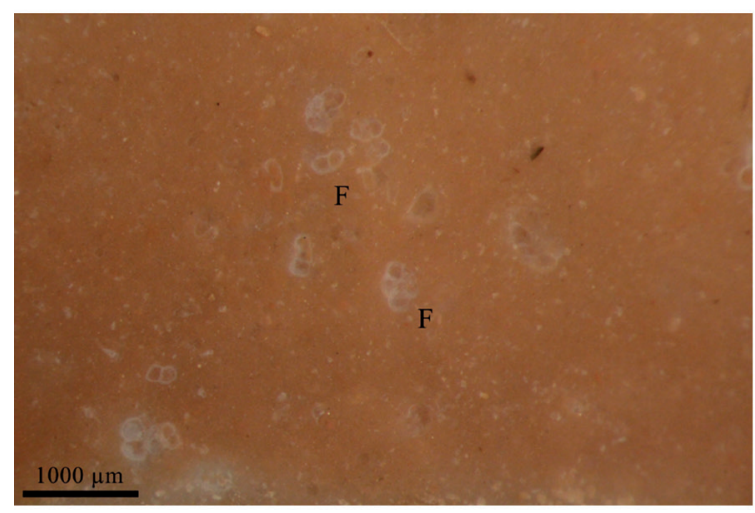

1. Cretaceous chert (silicite). Val di Non (Non valley), Trentino, Italy.

Scaglia Formation, Middle-Upper Cretaceous.

Cross sections of the Foraminifera Globotruncana $(\mathrm{F})$.

Unpolished surface. $40 \times$ magnification. Water immersion.

(Microphoto: M. Brandl).

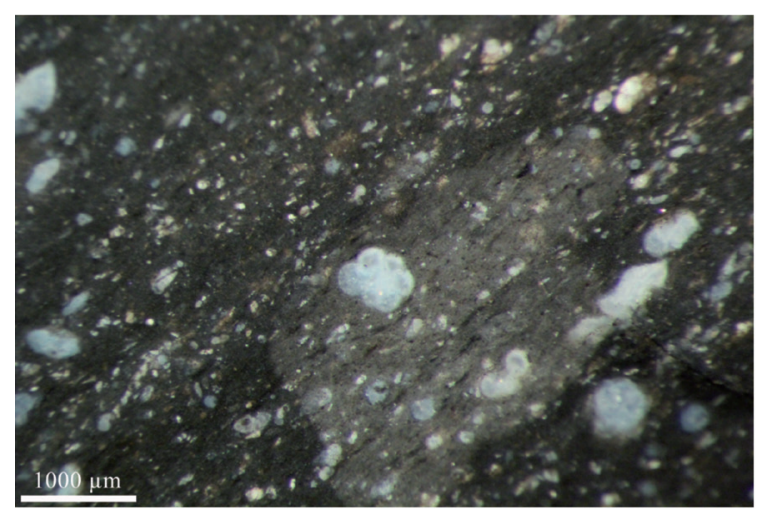

2. Cretaceous chert (silicite). Val di Non, Trentino, Italy (see No. 1).

Cross section of the Foraminifera Globotruncana (closeup).

Unpolished surface. $40 \times$ magnification. Water immersion.

(Microphoto: M. Brandl).

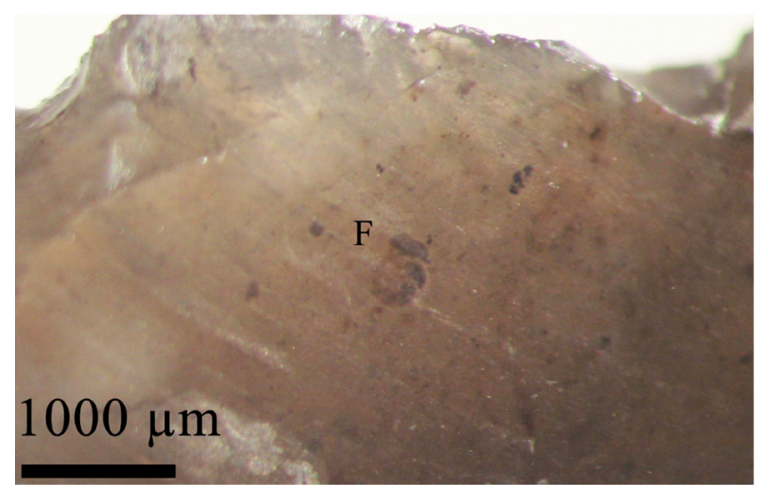

3. Obourg flint. Obourg, Belgium.

Craie de Obourg Formation, Senonian.

Unidentified Cretaceous foraminifer (F).

Unpolished surface. $40 \times$ magnification. Water immersion.

(Microphoto: M. Brandl).

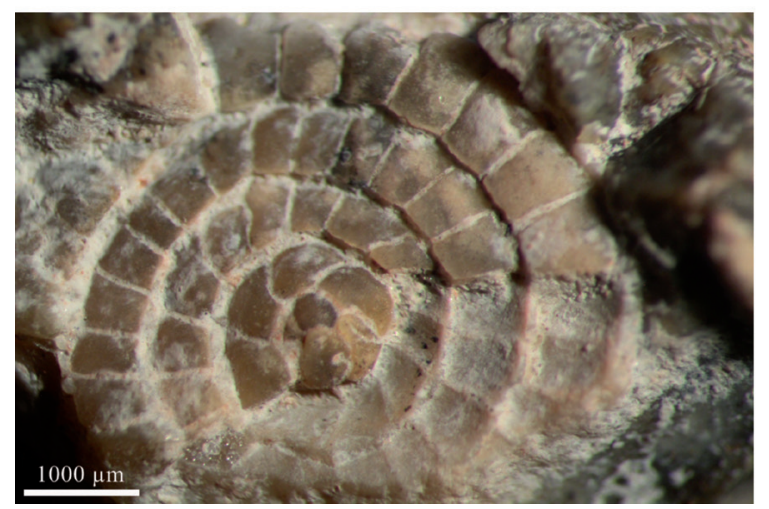

4. Chert. Artefact from the Krems-Wachtberg site, Austria.

Northern Lower Austrian palaeo-gravels. LowerMiddle Eocene with relations to the Waschberg Zone (?).

Nummulite (large foram).

Unpolished surface. $40 \times$ magnification. (Microphoto: M. Brandl). 
Marine sponge remains
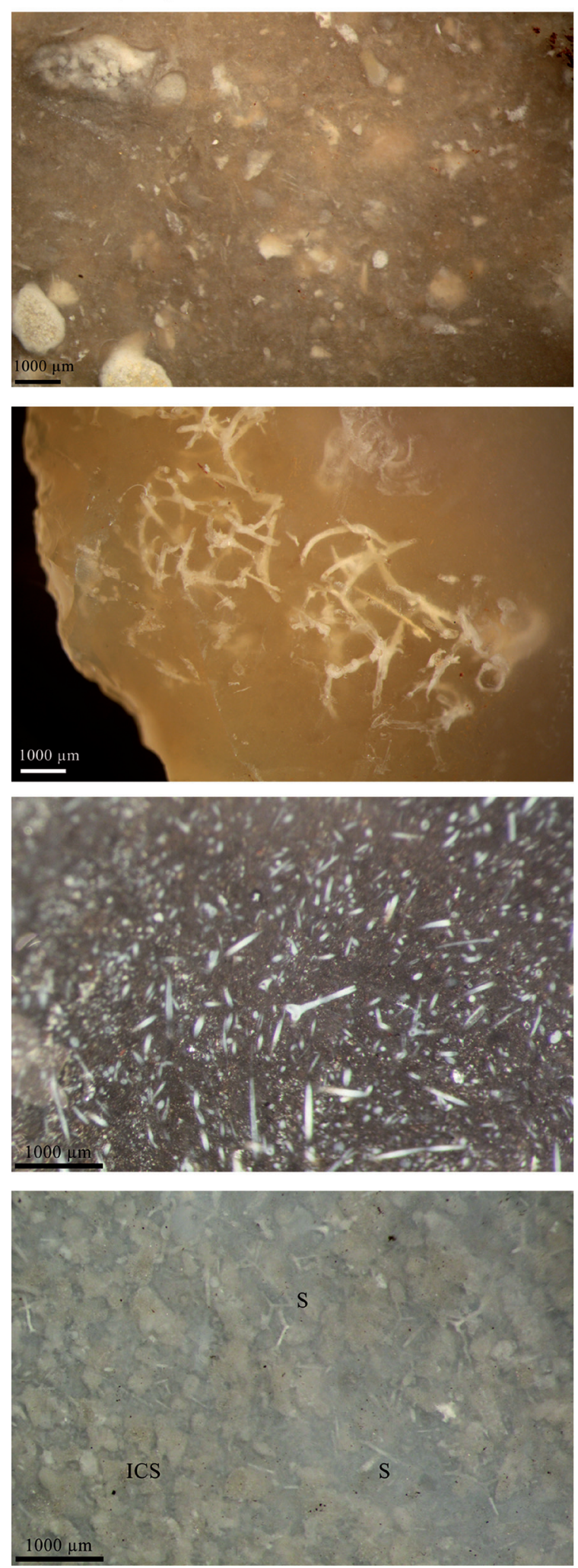

Plate 3
1. Craców "flint". Bębło, Poland.

Bedded limestone facies of the Craców-Wielún

upland, Upper Jurassic.

Disintegrated sponge body parts and tissue related to the sponge microbial megafacies.

Unpolished surface. $20 \times$ magnification. Water immersion.

(Microphoto: M. Brandl).

2. Berry flint. Meusnes, France.

"Silex blond de Berry", Turonian.

Articulated polygonal skeleton remains of Porifera.

Unpolished surface. $20 \times$ magnification. Water immersion.

(Microphoto: M. Brandl).

3. Spiculite. Danube river gravels near Krems, Austria.

Northern Calcareous Alps, Jurassic.

Monaxon spicules are the dominating fossil inclusions.

Unpolished surface. $40 \times$ magnification. Water immersion.

(Microphoto: M. Brandl).

4. Chert. Krumlovský les type I, Czech Republic. Upper Jurassic-Lower Cretaceous.

Polyaxial spicules of Porifera (S) and less silicified isometric cloudy residues of the host rock (ICS).

Unpolished surface. $40 \times$ magnification. Water immersion

(Microphoto: M. Brandl). 


\section{Echinodermata}
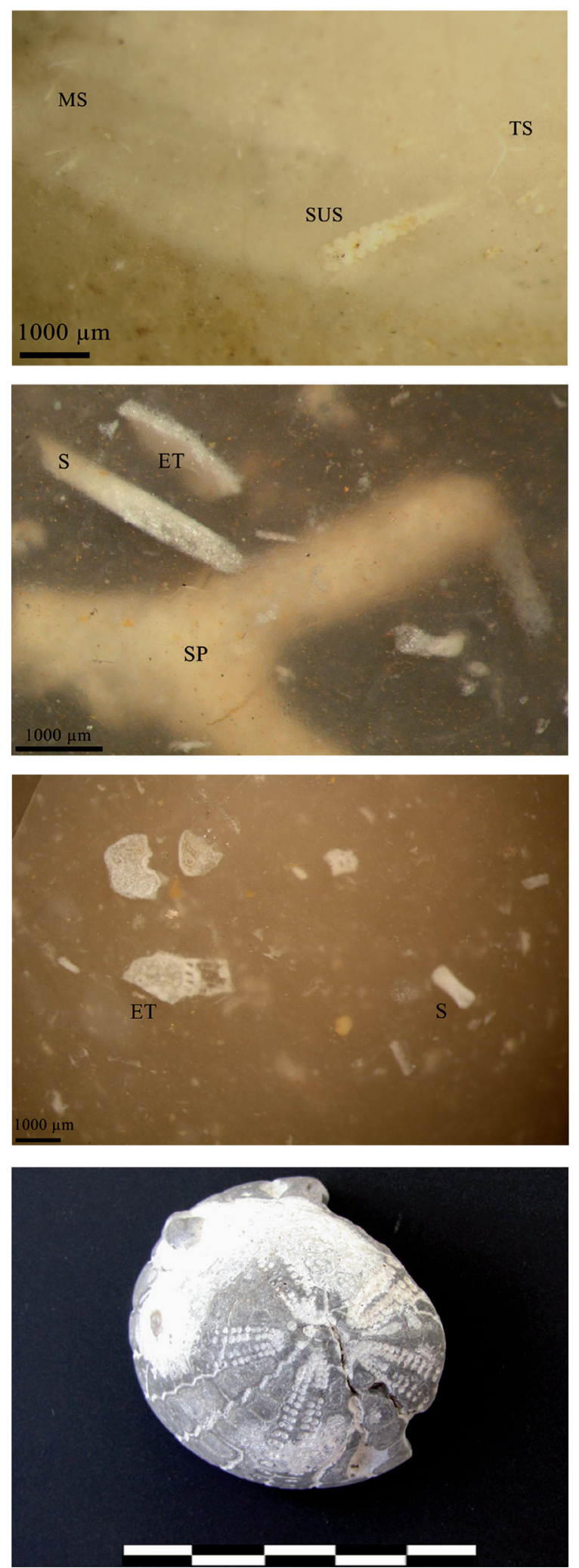

Plate 4
1. Erratic flint. Artefact from the Krems-Wachtberg site, Austria

Northern Bohemia or southern Poland, Upper Cretaceous.

Monactinal spicules (MS), tetractine spicules (TS) and cross section of a sea urchin spine (SUS).

Unpolished surface. $20 \times$ magnification. Water immersion.

(Microphoto: M. Brandl).

2. Craców "flint". Sąspów, Poland.

Bedded limestone facies of the Craców-Wielún upland, Upper Jurassic.

Large marine sponge remain (SP), broken spine (S) and test of echinoderms (ET) (sea urchins?).

Unpolished surface. $40 \times$ magnification. Water immersion.

(Microphoto: M. Brandl).

\section{Berry flint. Meusnes, France.}

"Silex blond de Berry", Turonian.

Spine (S) and tests (ET) of echinoderms (sea urchins).

Unpolished surface. $20 \times$ magnification.

(Microphoto: M. Brandl).

\section{Møn flint. Møn, Denmark.}

Maastrichtian flint layers, Late Cretaceous.

Complete silicified sea urchin test.

Unpolished surface. Lenght of the bar: $5 \mathrm{~cm}$. (Macrophoto: M. Brandl). 

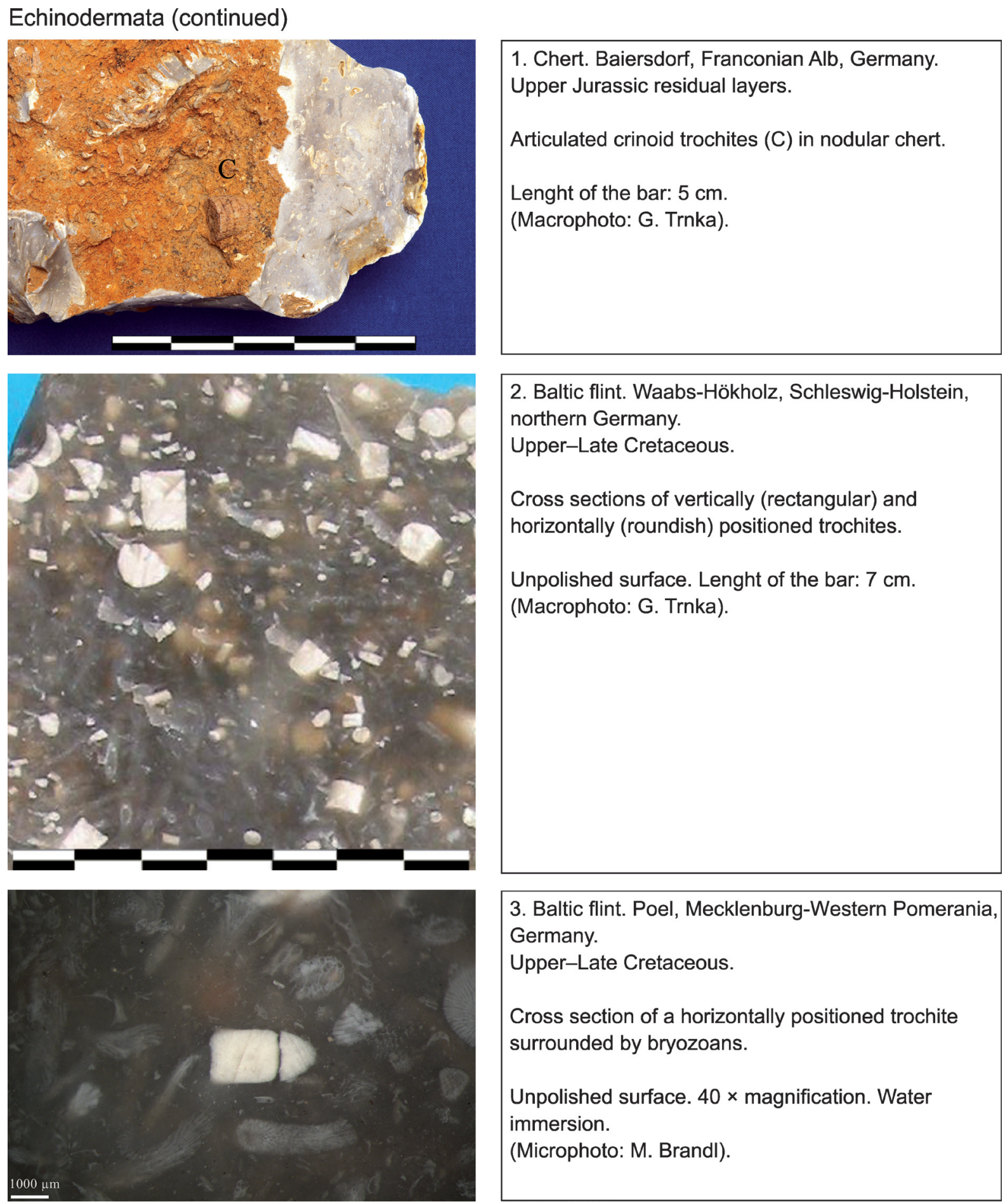

3. Baltic flint. Poel, Mecklenburg-Western Pomerania,
Germany.
Upper-Late Cretaceous.
Cross section of a horizontally positioned trochite
surrounded by bryozoans.
Unpolished surface. $40 \times$ magnification. Water
immersion.
(Microphoto: M. Brandl).

Plate 5 
Additional fossil inclusions
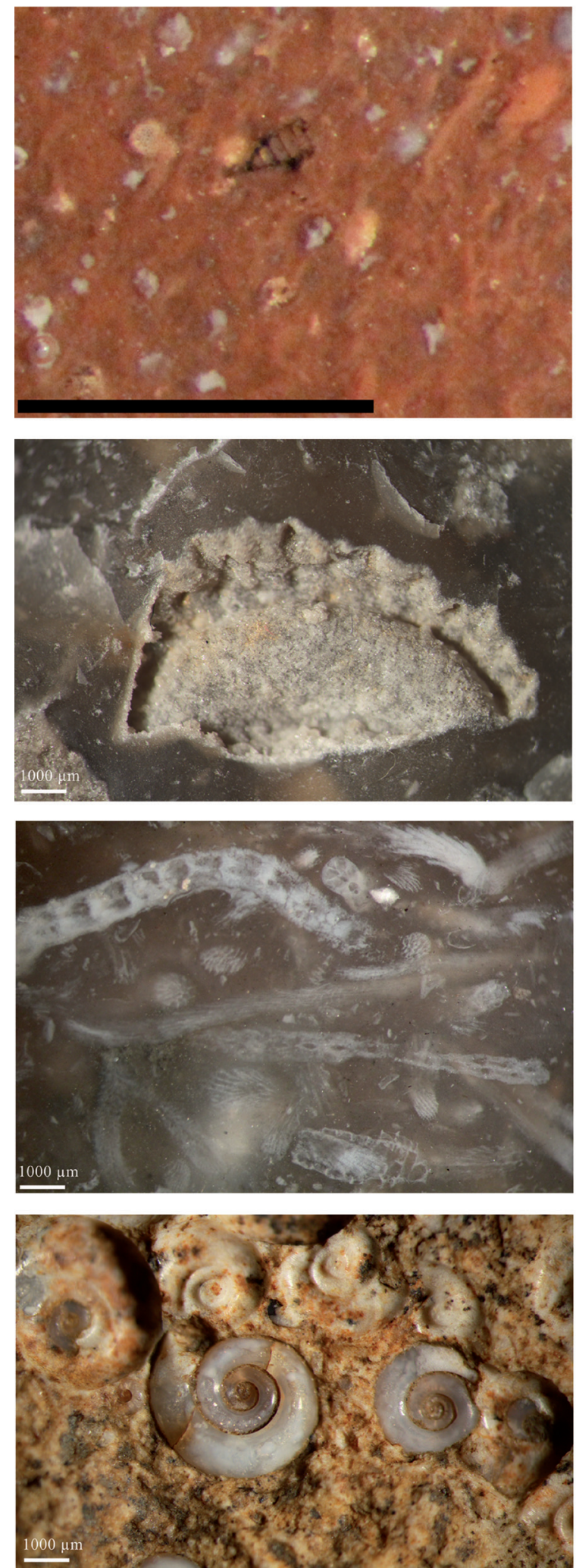

1. Radiolarite. Grubalacke source. Rofan Mountains, northern Tyrol, Austria.

Ruhpolding Formation, Lower-Middle Jurassic.

In addition to dominating radiolarians, a marine shell inclusion is present.

Unpolished surface. Length of the bar: $1 \mathrm{~mm}$. Water immersion.

(Microphoto: M. Brandl).

2. Craców "flint". Cajowice, Poland.

Bedded limestone facies of the Craców-Wielún

Upland, Upper Jurassic.

Poorly silicified imprint of a marine shell.

Unpolished surface. $40 \times$ magnification. Water immersion.

(Microphoto: M. Brandl).

3. Baltic flint. Poel, Mecklenburg-Western Pomerania, Germany.

Upper-Late Cretaceous.

Cross sections of bryozoan colonies.

Unpolished surface. $40 \times$ magnification. Water immersion.

(Microphoto: M. Brandl).

4. Lacustrine chert. Rein Basin, Styria, Austria.

Miocene, Lower Badenian.

Chalzedonised shells of Planorbis mantelli in silicified freshwater marl.

Unpolished surface. $20 \times$ magnification.

(Microphoto: M. Brandl). 
Non-fossil inclusions
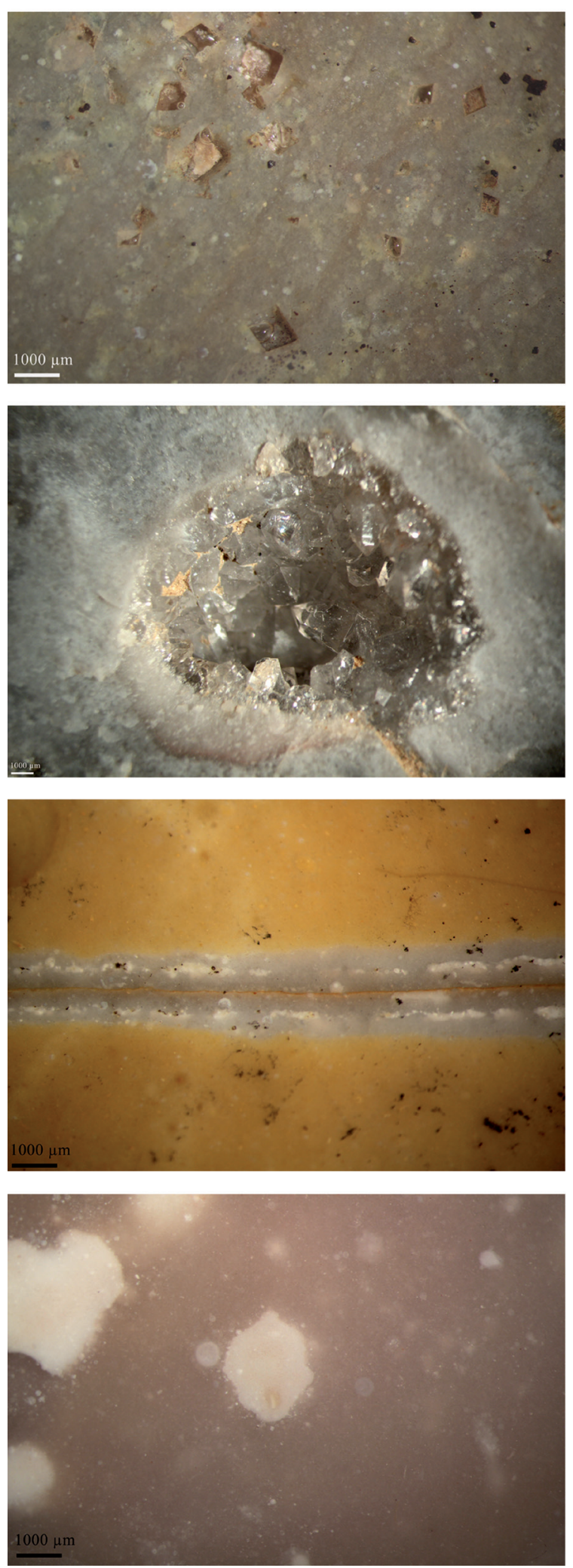

Plate 7
1. Radiolarite. Vienna Gemeindeberg, Austria. St Veit Klippen Belt, Upper Jurassic.

Trigonal cavities of foreign mineral inclusions (most likely calcite).

Unpolished surface. $20 \times$ magnification. Water immersion.

(Microphoto: M. Brandl).

2. Chert. Krumlovský les type I, Czech Republic.

Upper Jurassic-Lower Cretaceous.

Geode (cavity filled with small rock crystal points) in chert matrix.

Unpolished surface. $10 \times$ magnification.

(Microphoto: M. Brandl).

3. Cretaceous chert (silicite). Val di Non (Non valley), Trentino, Italy.

Scaglia Formation, Middle-Upper Cretaceous.

Chalcedony vein as secondary cleft filling.

Unpolished surface. $20 \times$ magnification. Water immersion.

(Microphoto: M. Brandl).

4. Cretaceous chert (silicite). Monte Baldo, Trentino, Italy.

Biancone Formation. Lower Cretaceous.

Intraclasts (white). Worked up material from the host rock formation is included in the silicified matrix.

Unpolished surface. $20 \times$ magnification. Water immersion.

(Microphoto: M. Brandl). 